Article

\title{
Assessment of Post-Earthquake Damage: St. Salvatore Church in Acquapagana, Central Italy
}

\author{
Gessica Sferrazza Papa ${ }^{1, *(1)}$ and Benedetta Silva ${ }^{2}$ (1) \\ 1 DABC Department of Architecture, Built Environment and Construction Engineering, Politecnico di Milano, \\ 20133 Milano, Italy \\ 2 DAStU Department of Architecture and Urban Studies, Politecnico di Milano, 20133 Milano, Italy; \\ benedetta.silva@polimi.it \\ * Correspondence: gessica.sferrazza@polimi.it; Tel.: +39-02-23994235
}

Received: 4 December 2017; Accepted: 15 March 2018; Published: 17 March 2018

\begin{abstract}
This article proposes a multidisciplinary approach for the assessment of seismic damage from the perspective of conservation and prevention. A comparison of the state of damage has been carried out in a case study, St. Salvatore church in Acquapagana (MC), as an example of church, which underwent two important seismic events in the Central Italy area, the 1997 and the 2016 earthquakes. The comparison of the state of damage passes through the following stages: (a) the territorial seismic overview; (b) the historical description and material analysis; (c) the identification of macro-elements with activated damage mechanisms; (d) the comparison between the two seismic events both from a territorial- and building-scale perspective. This work puts together the archived and the on-site survey data with those elaborated starting from seismogenic information, available from the National Seismological Institute, and it provides a strategy also for other similar conditions. This work is to be considered a contribution to a wider study that could be carried out in the areas hit by the 2016 earthquake. It could also represent a way to collect documentation in the post-earthquake phase, improving the effectiveness of procedures currently applied to the first level of damage assessment.
\end{abstract}

Keywords: damaged churches; historical masonry churches; 1997 Umbria-Marche earthquake; 2016 Central Italy earthquake

\section{Introduction}

Earthquakes pose a threat to our cultural heritage assets, constituted in part by churches. The seismic risk of the Italian territory is well known because of the many earthquakes that have occurred over the years. This type of risk is strictly related to the vulnerability of the buildings; indeed, working on them is necessary to preserve the national cultural heritage asset. In this regard, the efforts of researchers are focused on acquiring procedures to access in detail the vulnerability of churches and to think about intervention strategies. Since the 1976 Friuli earthquake, which caused severe damage to the heritage building stock, churches have started to be studied in relation to their evidence of vulnerability under seismic actions. The study of vulnerability is strictly related to the study of damage. The post-earthquake observation of damage led to the elaboration of the forms of damage assessment of churches, whose current version [1] was approved with Decree DPCM of 23 February 2006, becoming a national standard. This survey form associates a typical mechanism of collapse to each macro-element, a well-recognizable structural unit. The observation of damage after the Friuli earthquake of 1976 and its interpretation converged in a book, Le chiese e il terremoto [2], which can be considered the basis of all the subsequent studies on the vulnerability of churches. With the 1997 Umbria-Marche earthquake, the observations of the effectiveness of strengthening and repairing interventions started, allowing one to express considerations about interventions and to collect a large 
amount of data, as specified in [3]. As a consequence of this post-earthquake experience, a manual of best practices was written, Codice di pratica (The Code of Practice) [4]. It was published by the Regional Authority of Marche, as a tool in support of professionals that would operate in reconstruction and repairing, suggesting a suitable modus operandi. In addition to this manual, other similar ones were issued in those years, dealing with best practices for interventions, such as [5-10].

Other observations of damage have followed throughout the years, for the many earthquakes that have occurred in Italy. Among others, some of the episodes with the corresponding studies are: Lunigiana and Garfagnana, 1995 [11]; Umbria and Marche, 1997 [12,13]; Molise, 2002 [14]; L'Aquila, 2009 [15-21]; and Emilia, 2012 [22,23].

Moreover, several studies have been carried out to assess the seismic vulnerability of churches and to understand the relative structural behavior under seismic actions by numerical analysis [24-27]. The vulnerability assessment of churches was also studied by some researches from a large-scale perspective (i.e., [28]).

Considering this context and following the recommendations of the Italian Guidelines for Cultural Heritage [29], in accordance with the Italian Building Code (N.T.C. 2008) [30], this article proposes a procedure for the assessment of the damage of churches with a multidisciplinary approach, in line with Principle 1.1 of the ICOMOS Charter [31]. This methodology is inserted in a panorama of studies, such as [32-34], which believe in the importance of achieving deep knowledge of the historical building, the object of the study, through the contribution provided by different disciplines, with the final aim of preserving the cultural heritage asset. The multidisciplinary approach in the following work is achieved observing the impact of the earthquake on the church case study from different perspectives, taking into account several aspects: the seismogenic system, the registered peak ground acceleration (PGA) values, the history of the church with the analysis of the masonry walls and the executed interventions with the two post-earthquake states of damage (1997-2016). Indeed, with such an approach, the observation of the post-earthquake damage and the study of the interventions executed on a historical building become part of a wider process, which contributes to achieve the aim of conservation and prevention of damage caused by earthquakes [35] (Chapter 29, paragraphs 1,2,4).

The procedure, exposed here, is applied to the single-nave St. Salvatore church, taken as a case study representative of those churches that underwent earthquakes and interventions in the time lapse between the events. Moreover, the following work intends to provide a contribution to ongoing studies (e.g., [36]) on the state of damage of the churches of Central Italy damaged by the 2016 earthquake. In particular, in [37], a set of single-nave churches, located in Umbria, Perugia, Ascoli Piceno, Macerata and Pesaro-Urbino, is used to compare the surveyed state of damage with the expected damage, according to predictive methods $[38,39]$.

Figure 1 summarizes the procedure followed to investigate the state of damage of St. Salvatore church, which is reflected in the structure of the article. Starting from a territorial analysis (Section 2.1) of the seismicity of the area (the seismogenic source system, active faults, expected accelerations and the catalogue of seismicity), entering into the detail of the historical description and material characterization of the church (Section 2.2) and the identification of the existing macro-elements (Section 2.3), the article compares the two seismic events, the 1997 Umbria-Marche earthquake and the 2016 Central Italy earthquake: first, from a territorial perspective and, later, from a building-scale point of view. The final sections are dedicated to the discussion of the evidence and to sum up the results of the study.

All in all, this work will point out how from a multidisciplinary approach for the assessment of damage it is possible, not only to obtain information regarding the technical aspects about the effectiveness of interventions and situations to be avoided for historical masonry churches, but also to interpret the damage, including seismic and territorial aspects. Meanwhile, another indirect outcome of this approach is the collection of territorial- and building-scale information. 


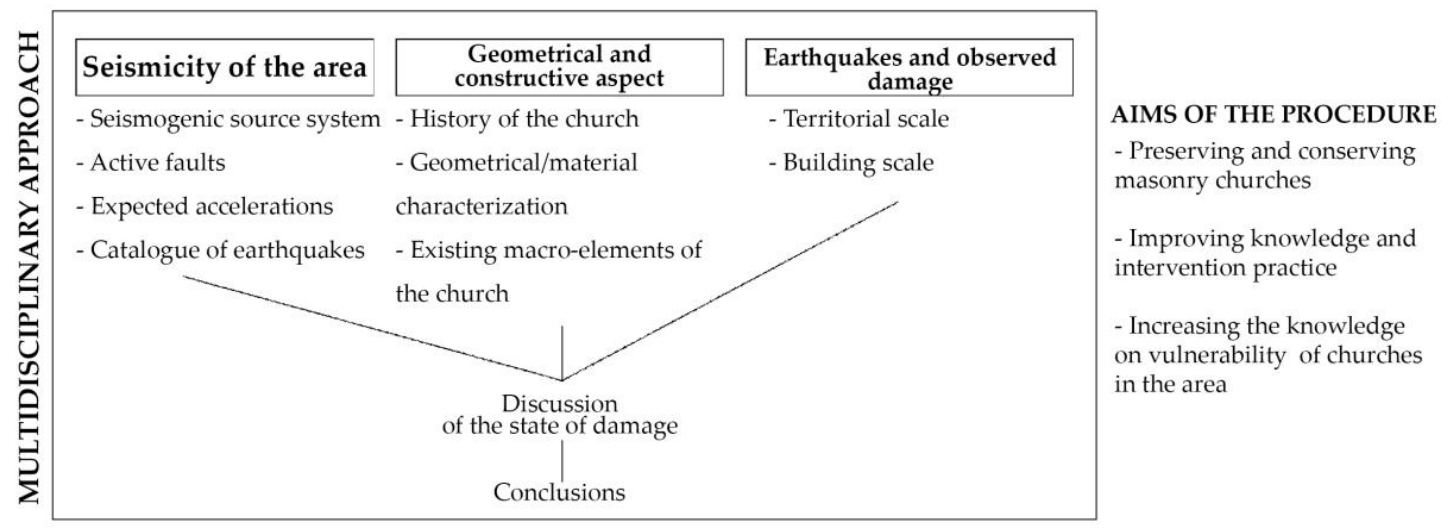

Figure 1. Diagram of the multidisciplinary procedure followed in the article.

\section{The case study of San Salvatore church in Acquapagana}

\subsection{Territorial Overview}

For the study, the starting point was the identification of a church in the territory. San Salvatore Church is the only church of Acquapagana, a small hamlet in the municipality of Serravalle di Chienti, in the province of Macerata (Italy). The development of the urban center follows a south-north axis, and the church is located in the southern part of the hamlet (Figure 2a). It is part of an isolated monastic complex, developing with a west-east direction (Figure 2b). This geographical orientation will be useful for the final considerations about the state of damage post the 1997 and post the 2016 earthquakes.

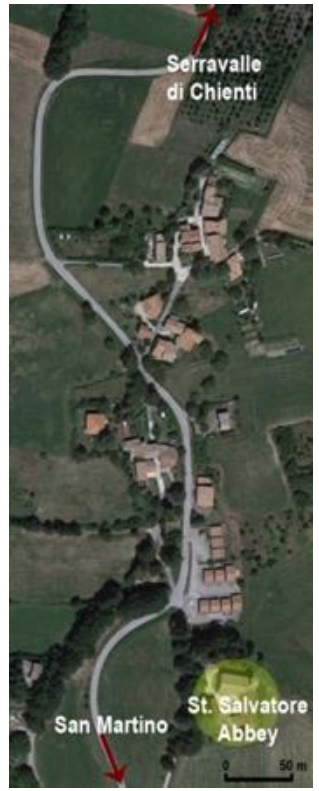

(a)

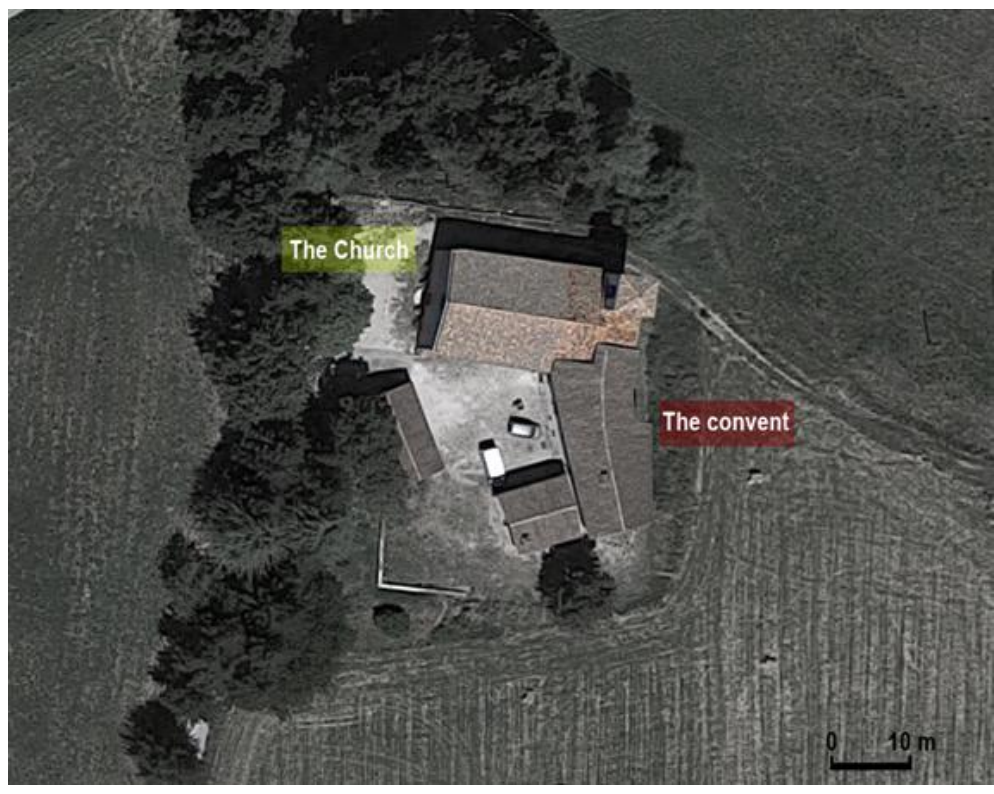

(b)

Figure 2. Aerial views. (a) The location of St. Salvatore Abbey in Acquapagana [40]; (b) the complex of St. Salvatore Abbey: the church (in the north) and the monastery building (in the east). Coordinates: $42^{\circ} 59^{\prime} 00.5^{\prime \prime} \mathrm{N} 12^{\circ} 55^{\prime} 49.2^{\prime \prime} \mathrm{E}$ [40].

The seismicity of this geographical area is well known, as the system of seismogenic sources (Figure 3a), the map of active faults (Figure 3b), the seismic hazard map of the Marche region (Figure 4a), the seismic catalogue (Table 1) and the histogram of seismicity of Serravalle di Chienti (Figure 4 b) demonstrate. 


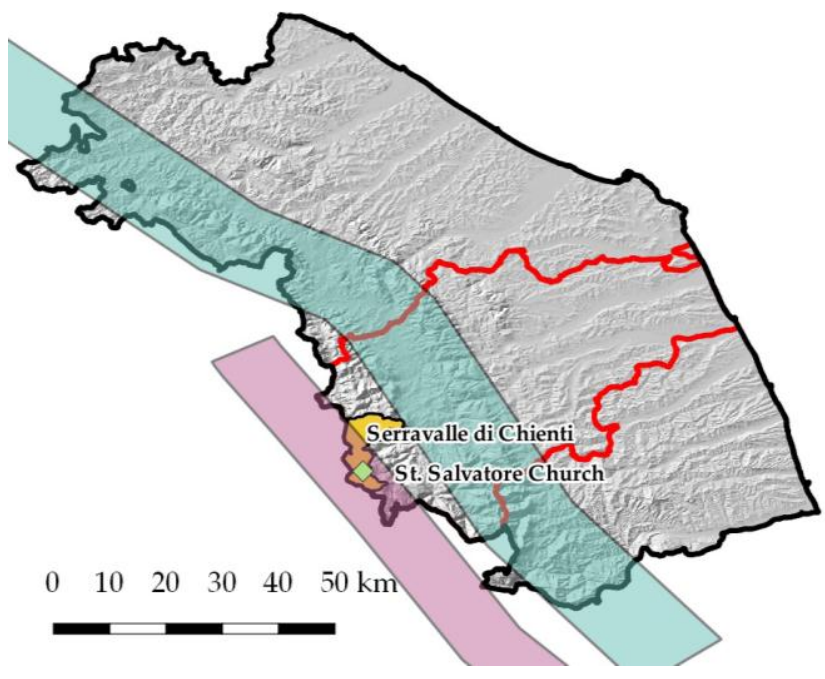

(a)

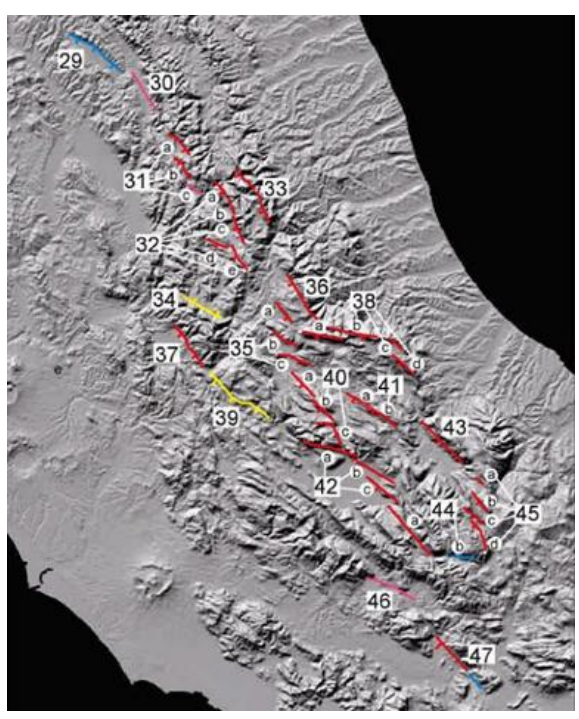

(b)

Figure 3. (a) The map shows the Marche region (black line), with Macerata province highlighted (red line) and Serravalle di Chienti municipality (yellow area). The church is identified with a green square; two stripes represent the major seismogenic faults that cross the territory, Colfiorito-Campotosto fault (purple stripe) and Vettore-Porche-Bove (light blue stripe). Source data: [41]. (b) The map shows the principal active faults of the Central Apennine Mountain chain: Gubbio (29), Gualdo Tadino (30), Colfiorito (31), Norcia (32), Mt.Vettore (33), Leonessa (34), Alta Valle dell'Aterno (35), Mt. Della Laga (36), Rieti (37), Campo Imperatore-Assergi-Mt. Cappucciata (38), Valle del Salto (39), Campo Felice-Colle Cerasito/Ovindoli-Pezza (40), Media Valle dell'Aterno (41), Fucino (42), Mt. Morrone (43), Alta Valle del Sangro (44), Aremogna-Cinquemiglia (45), Sora (46), St. Pietro Infine (47) [42] (p. 10).

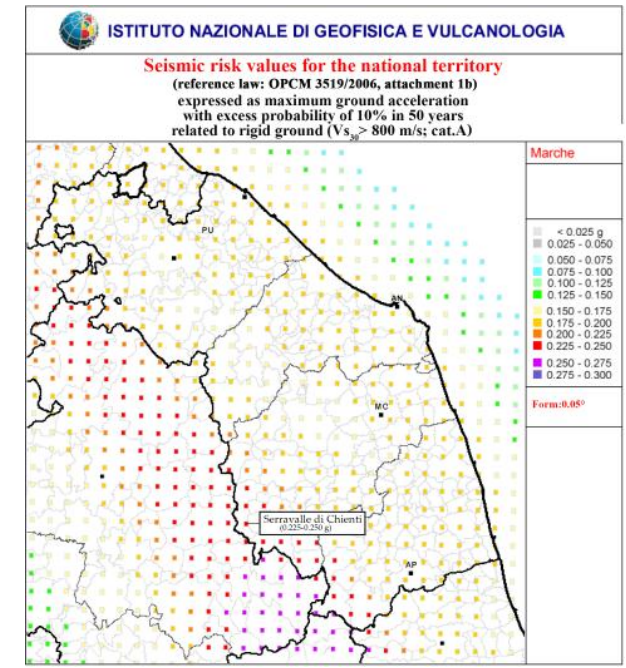

(a)

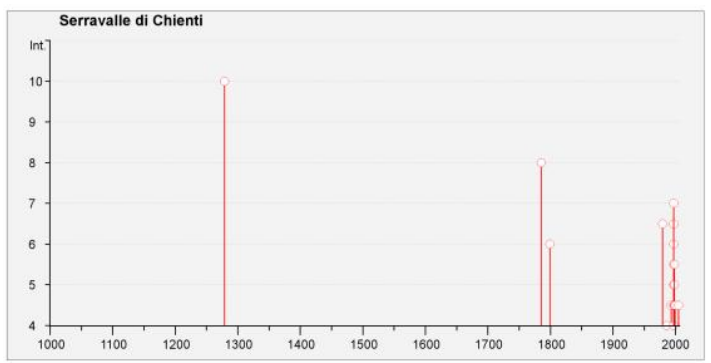

(b)

Figure 4. (a) Marche seismic hazard map. Serravalle di Chienti's value of peak ground acceleration (PGA) (\% g) is pointed out [43]. (b) The histogram represents in the $x$ axis the year of occurrence of the earthquake episode and on the y axis the intensity value [44]. 
Table 1. Table of major seismic events for the Serravalle di Chienti area. Data source [44].

\begin{tabular}{|c|c|c|c|c|}
\hline $\begin{array}{l}\text { Microseismic } \\
\text { Intensity }\end{array}$ & Date Time & Localization & $\begin{array}{l}\text { Epicenter } \\
\text { Intensity }\end{array}$ & $\begin{array}{c}\text { Moment } \\
\text { Magnitude }\end{array}$ \\
\hline 10 & $3004127918: 00$ & Camerino & 9 & 6.31 \\
\hline 8 & $0305178502: 30$ & Alta valle del Chienti & 7 & 5.14 \\
\hline 6 & $2807179922: 05$ & Appennino Marchigiano & 9 & 6.13 \\
\hline NF & 10091919 16:57:20 & Piancastagnaio & $7-8$ & 5.32 \\
\hline $6-7$ & 1909 1979 21:35:37 & Valnerina & $8-9$ & 5.86 \\
\hline 4 & 13101986 05:10:01 & Appennino Umbro-Marchigiano & $5-6$ & 4.65 \\
\hline 3 & 0307 1987 10:21:58 & Porto San Giorgio & & 5.09 \\
\hline $4-5$ & 0406 1993 21:36:51 & Nocera Umbra & $5-6$ & 4.50 \\
\hline $4-5$ & 05061993 19:16:17 & Gualdo Tadino & 6 & 4.74 \\
\hline 4 & $1507199708: 51$ & Appennino Umbro-Marchigiano & $4-5$ & 3.69 \\
\hline $5-6$ & 03091997 22:07:30 & Appennino Umbro-Marchigiano & $5-6$ & 4.56 \\
\hline 5 & 07091997 23:28:06 & Appennino Umbro-Marchigiano & $5-6$ & 4.38 \\
\hline $4-5$ & $0909199716: 54$ & Appennino Umbro-Marchigiano & $5-6$ & 4.07 \\
\hline $4-5$ & 10091997 06:46:51 & Appennino Umbro-Marchigiano & 5 & 4.16 \\
\hline 7 & 26091997 00:33:13 & Appennino Umbro-Marchigiano & & 5.70 \\
\hline $6-7$ & 03101997 08:55:22 & Appennino Umbro-Marchigiano & & 5.25 \\
\hline 6 & 06101997 23:24:53 & Appennino Umbro-Marchigiano & & 5.46 \\
\hline 7 & 14101997 15:23:11 & Appennino Umbro-Marchigiano & $7-8$ & 5.65 \\
\hline $4-5$ & 0911 1997 19:07:33 & Appennino Umbro-Marchigiano & $5-6$ & 4.90 \\
\hline 5 & 07021998 00:59:45 & Appennino Umbro-Marchigiano & $5-6$ & 4.43 \\
\hline $4-5$ & 16021998 13:45:45 & Appennino Umbro-Marchigiano & 5 & 4.03 \\
\hline $5-6$ & 2103 1998 16:45:09 & Appennino Umbro-Marchigiano & 6 & 5.03 \\
\hline 5 & 2603 1998 16:26:17 & Appennino Umbro-Marchigiano & 6 & 5.29 \\
\hline $5-6$ & 05041998 15:52:21 & Appennino Umbro-Marchigiano & 6 & 4.81 \\
\hline $4-5$ & 11081998 05:22:59 & Appennino Umbro-Marchigiano & $5-6$ & 4.53 \\
\hline $4-5$ & 29111999 03:20:34 & Appennino Centrale & $5-6$ & 4.38 \\
\hline NF & 09122004 02:44:25 & Zona Teramo & $5-6$ & 4.18 \\
\hline $2-3$ & 12042005 00:31:52 & Maceratese & $4-5$ & 4.16 \\
\hline $4-5$ & 15122005 13:28:39 & Valle del Topino & $5-6$ & 4.66 \\
\hline $3-4$ & 10042006 19:03:36 & Maceratese & 5 & 4.51 \\
\hline
\end{tabular}

The territory of Serravalle di Chienti is in the Colfiorito-Campotosto seismogenic source and near that of Vettore-Porche-Bove (Figure 3a). In these areas, active faults are concentrated (Figure 3b), and earthquakes, therefore, are generated. For Serravalle di Chienti, values of peak ground acceleration (PGA) between 0.225 and $0.250 \mathrm{~g}$ are expected, according to the map in Figure 4a. These values are useful in the perspective of damage prevention, but also to express an evaluation about accelerations occurring during a seismic event. The recurrence of earthquakes in this area is confirmed by Table 1 and Figure $4 \mathrm{~b}$, where the correspondent microseismic intensity and the moment magnitude of the seismic events from 1279-2006 for Serravalle di Chienti are reported. This table helps to have a perceptive of how many earthquakes churches located in that territory could have undergone. Most of the listed events belong to the seismic sequence corresponding to the 1997 Umbria-Marche earthquake, labelled as Appennino Umbro-Marchigiano.

\subsection{Historical Description and Material Analysis of the Building}

The original nucleus of the monastic complex of Acquapagana goes back to the XI Century: Saint Romualdo built both the church and the monastery in 1007. This date is confirmed by Lodovico 
Jacobini, a historian who found the complex in 1653, thanks to a parchment of 1063, which has been lost [45].

The church is an example of the Gothic-Umbrian style [46]: the smooth stone of the portal and of the rosette, the horizontal frame on the façade, the buttresses and the single windows on the lateral walls are clearly elements of this architectural period and of the geographical area under examination. Entering more into detail, on the west side of the church (Figure 5b), the principal façade appears, shaped as a simple hut with two openings: a portal, with a white stone frame, and a rose window. On the lateral sides (Figure 5a,c), the façades are articulated with buttresses to balance the thrust of the inner triumphal arches. In these walls, there are few openings: two small ones on the south side (Figure 5c) and one on the north and east side (Figure 5a,d). According to [45], other information on the church is dated 1737. At that time, according to the inventory of Camerino archbishopric's archive, the bell tower appeared on the main façade. It is assumed that the bell tower on the north side of the presbytery was built later. In 1960, the wooden roof was replaced with a concrete slab and a concrete curb [45], also visible in the graphic documentation of the 1997 earthquake, and then, after the evidence of the damage caused [46], the roof was rebuilt with a light timber structure [45].

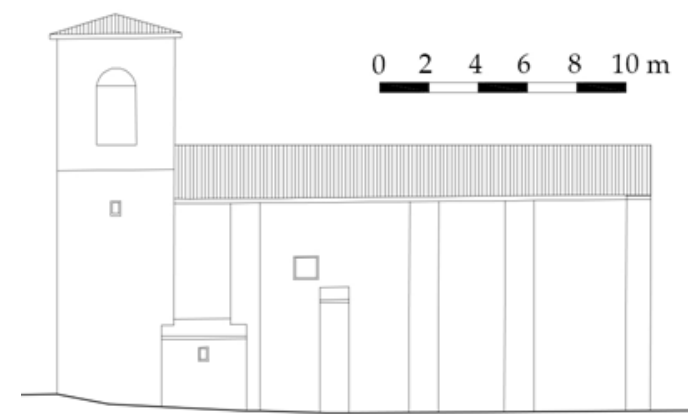

(a)

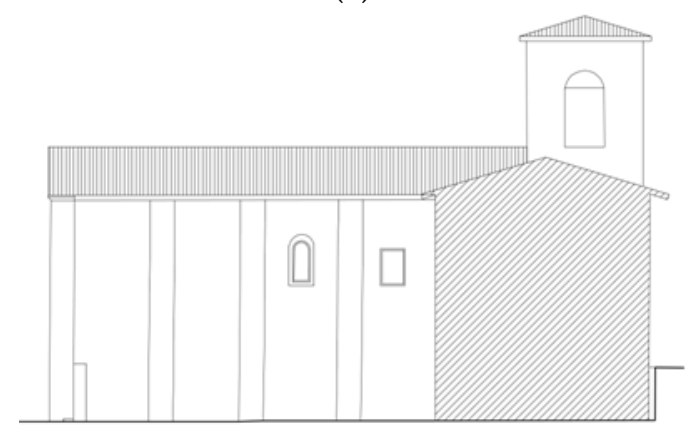

(c)

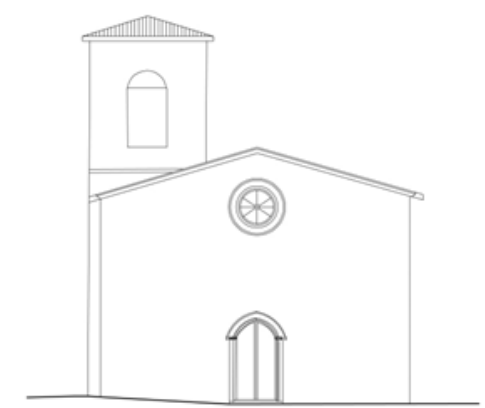

(b)

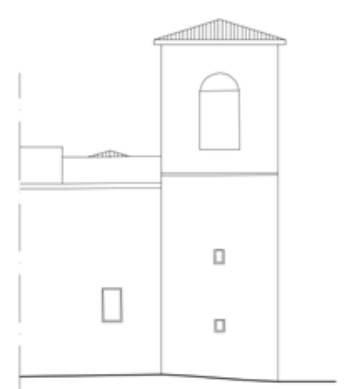

(d)

Figure 5. Geometrical survey of the church [47]. (a) North elevation of St. Salvatore church; (b) principal (west) façade of St. Salvatore church; (c) south elevation of St. Salvatore church; (d) east elevation of St. Salvatore church.

Regarding the planimetric configuration, the examined church consists of a single rectangular nave surrounded by continuous stone-framed masonry walls with an apse that ends the church on the back side and gives access to the bell tower, remaining perfectly in axis with the entrance (Figure 6a). A stair located in the southwest corner of the nave allows one to enter the timber choir above the principal entrance (Figure $6 \mathrm{~b}$ ). The nave is marked by triumphal arches with a regular inter-beam distance to provide support to the principal structure of the timber roof, which replaced the pre-existent concrete roof after the 1997 earthquake. Today, the roof structure is clearly visible: simple beams, running along the width of the church, bearing a secondary structure made of timber joists which provide the support to the roof (Figure $6 \mathrm{c}, \mathrm{d}$ ). 


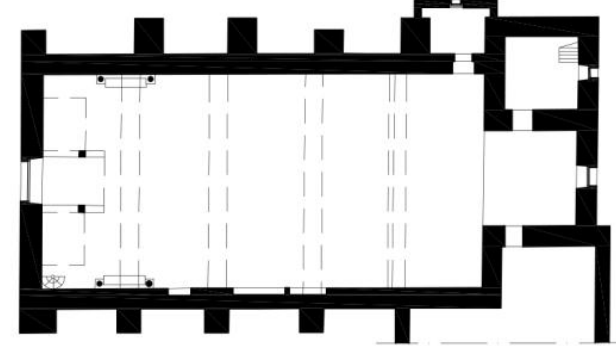

(a)

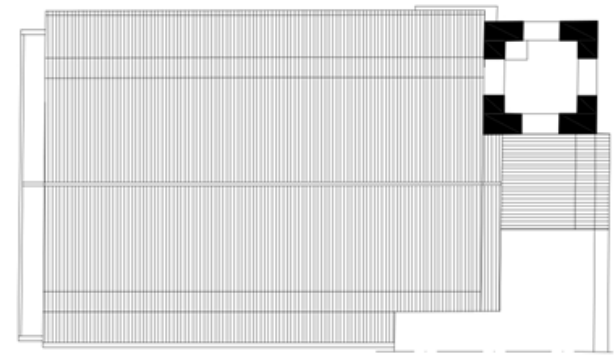

(c)

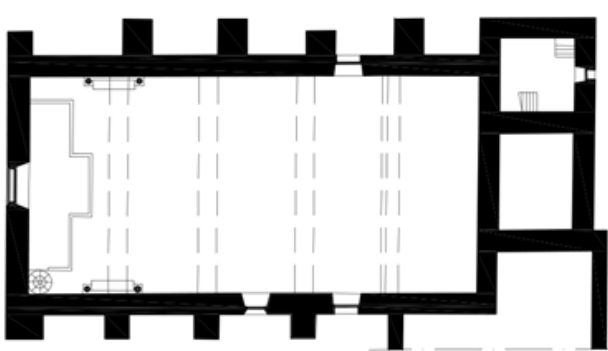

(b)

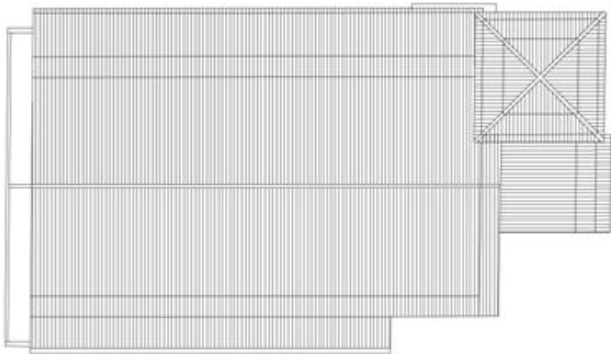

(d)

Figure 6. Geometrical survey of the church [47]. (a) Entrance-level plan of St. Salvatore church; (b) choir-level plan of St. Salvatore church; (c) plan at the bell tower opening level; (d) roof plan.

A fundamental step considered in the comprehension of the construction history of the church is the analysis of masonry. The first necessary action is the analysis of texture to understand how it was built. The correspondence to the "rule of the art" was used to assess the seismic vulnerability of the church masonry walls. With this term is meant the totality of all those constructive techniques that guarantee good behavior and ensure compactness and monolithism [48] (p. 238), through quality evaluation criteria and the identification of possible phenomena of instability or degradation.

The focus was set on the façade, extracting and analyzing a portion of $200 \mathrm{~cm}$ of width and $90 \mathrm{~cm}$ of thickness (see the red square in Figure 7a and redrawn in Figure 7b).

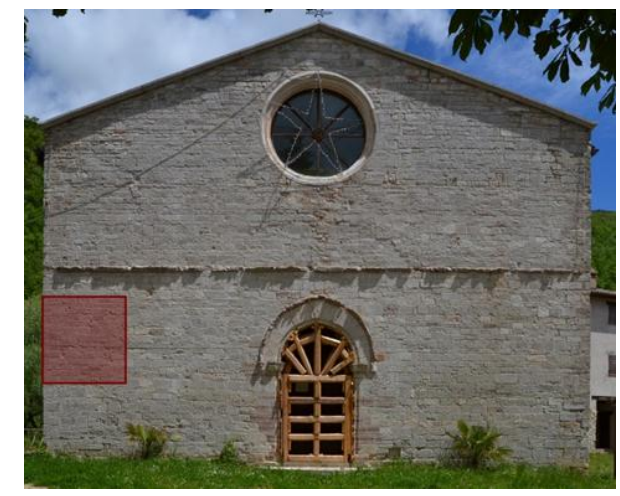

(a)

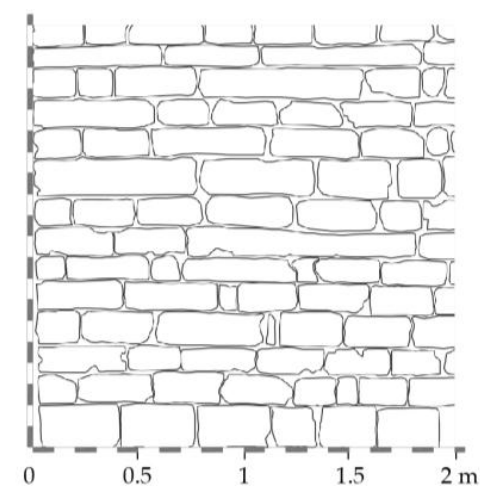

(b)

Figure 7. (a) Part of the investigated façade; (b) redrawn of a portion of the wall of the façade of the church $(2.00 \times 2.00 \mathrm{~m})$.

For the global assessment of masonry quality, the selected specimen has been evaluated, following the indications, given in [48], by which seven factors, which influence the good realization of masonry, 
are identified. Each factor is evaluated as: respected, or partially respected, or not respected. The seven factors are:

- Good quality of the mortar.

- Presence of bond stones, or stones passing through the entire thickness of the wall.

- Shape of the elements.

- Dimension of the elements.

- Presence of staggering in the vertical joints.

- Presence of horizontal rows.

- Good quality of resistant elements.

These evaluation criteria help with the comprehension of the response of a masonry panel to gravity and seismic actions, and they allow one to identify parameters that, if present, guarantee the masonry quality. The considered panel is assumed to be subject to vertical loads (both concentrated and distributed) in the middle plane and orthogonal to it. Each parameter is described for every action with a score, which contributes to the definition of the final wall quality index. This index corresponds to different categories for the quality of masonry ( $\mathrm{A}=$ good masonry behavior; $\mathrm{B}=$ average masonry quality; $\mathrm{C}=$ insufficient behavior).

Regarding St. Salvatore church, stone elements do not exhibit degradation phenomena, have a regular and squared shape and well-defined edges (Figure 8a). This is clearly visible in lateral walls and in the principal façade, while the state of conservation and the pattern of the material are hidden by the plaster in the east front and in the annexed body in the north side of the church. Prevalent dimensions are a 30-50- $\mathrm{cm}$ length, a 10-25-cm height and a 10-20-cm thickness, but many elements are also present with a major dimension of $70 \mathrm{~cm}$. The wall section, analyzed with the image of the 1997 earthquake damage, shows the presence of a rubble masonry: three leaves, two external layers with a filling material, linked with some cross blocks (Figure 8b). Mortar joints are in good condition and well preserved: large stone elements and thin layers of mortar are well proportioned. Horizontal rows (Figure 8c) characterize all the length of the wall without interruption, while the splitting of vertical joints is only partially respected (Figure $8 d$ ), because some joints are not in an intermediate position with respect to the stone element. Analyzing the corners, it is possible to observe the presence of cross blocks, which help to assume a good connection between lateral walls and the façade. The global evaluation of the masonry is summarized in Table 2: a section is dedicated to show the photographic details of the masonry, another to show the schemes, one more to show the descriptions of the techniques of construction and materials and one to show the geometrical stone characteristics; finally, the last section is dedicated to the correspondence of the seven factors with a final evaluation of the quality of the masonry, resulting in being of good quality. 
Table 2. Wall quality index evaluation. Source of the axonometry and section images: [49].

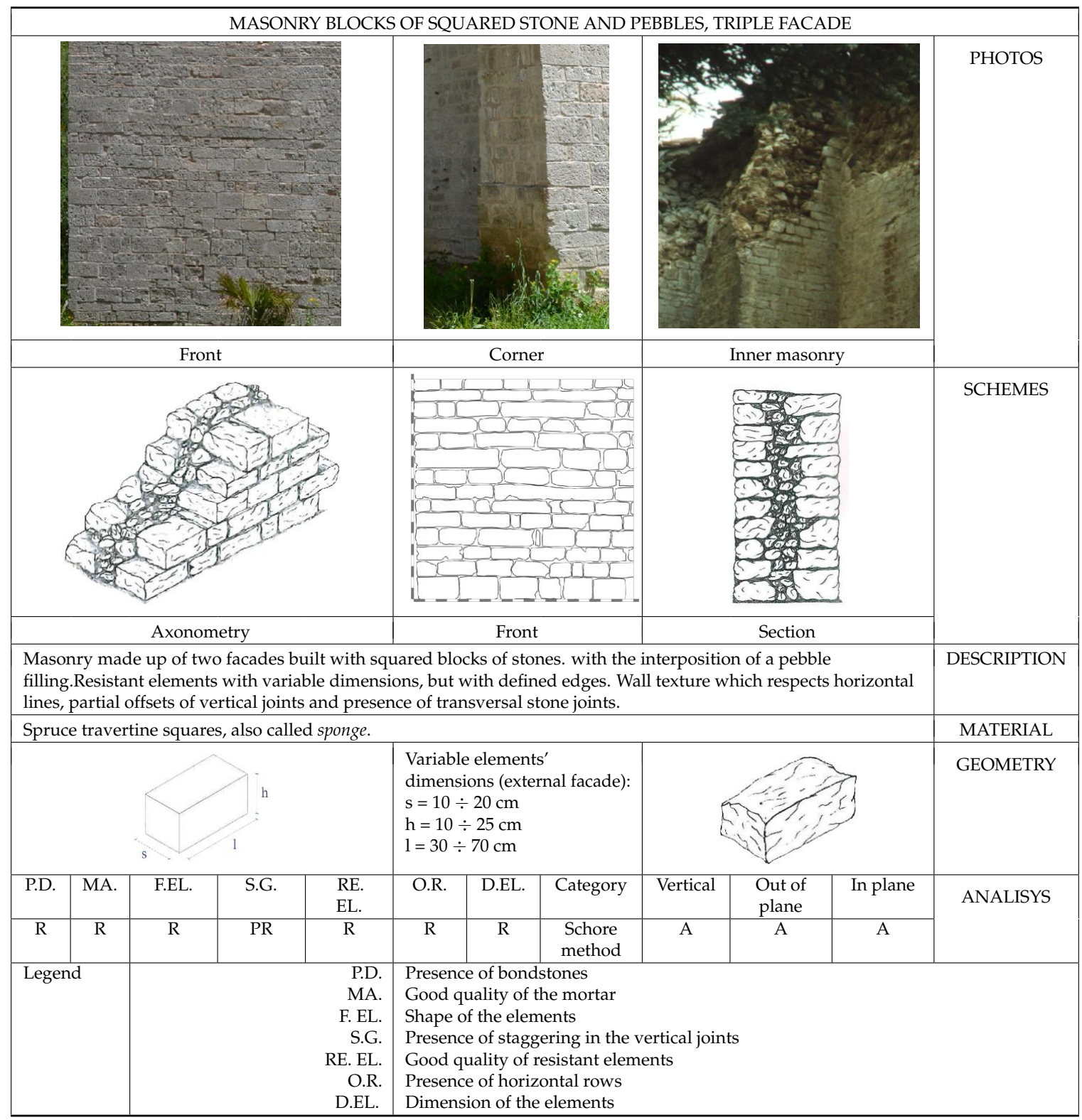

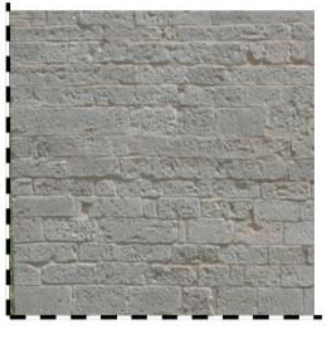

(a)

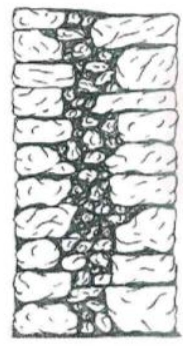

(b)

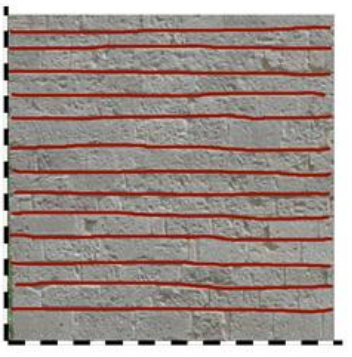

(c)

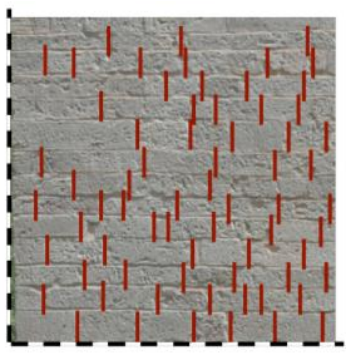

(d)

Figure 8. (a) Quality of mortar, form of resistant elements, dimensions of elements, quality of resistant elements; (b) presence of cross blocks [49]; (c) splitting of vertical joints; (d) presence of horizontal rows. 


\subsection{The Identification of Existing Macro-Elements}

Earthquakes, which have occurred in Italy in the last few decades, have produced severe damage to the masonry building stock: especially churches have been shown to be particularly vulnerable also to low seismic accelerations. The reason for such vulnerability is connected to the church typological characteristics, such as the presence of slender walls, heavy construction elements producing thrust actions on walls and the absence of diaphragm slabs.

Systematic studies of church damage have been carried out since the 1976 Friuli earthquake. Indeed, a process of damage data collection has started from that occasion and has been continued also after the following major earthquakes. The observation of the structural behavior of churches clearly allows one to understand typical aspects of the response during earthquakes, identifying well-recognizable parts of the building that show unity in their behavior during earthquakes, labeled as macro-elements [2].

Since the study, Le chiese e il terremoto [2], a strong connection between macro-elements and collapse mechanisms has been pointed out, ending with the elaboration of the form of damage for churches [1], based on 28 kinematic mechanisms, including both out-of-plane and in-plane collapse modalities [50]. The survey form for the damage of churches is used for the first-level damage assessment, to have accessibility and the state of damage produced by the seismic event. It is filled by a team of experts, following the procedure indicated in a specific manual [51]. This is an essential action that helps to define the planning of safety interventions and the next repairing activities. For the present study, the existing macro-elements of the church have been identified. The tridimensional model (Figure 9) clearly shows the main structural units; out of all the possible macro-elements, only a few are present: façade, lateral walls, bell tower, apse, triumphal arch. Consequently, kinematic mechanisms have been associated with each macro-element.

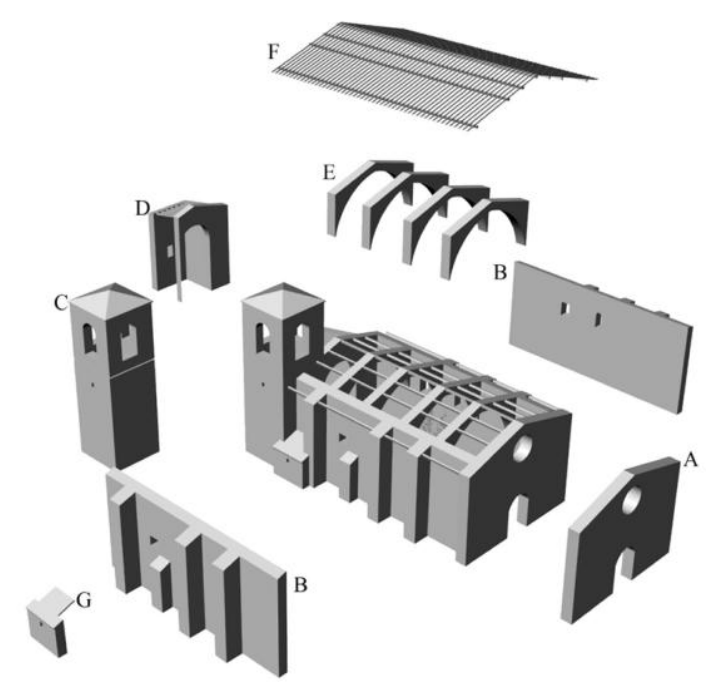

Figure 9. Macro-elements of St. Salvatore church. (A) Façade; (B) lateral walls; (C) bell tower; (D) apse; (E) triumphal arch; (F) beams of the roof; $(\mathrm{G})$ annex building.

The possible kinematic mechanisms, in the case of St. Salvatore church, are the following:

- Overturning of the façade (mechanism 1)

- Mechanisms of the upper part of the façade (mechanism 2)

- In-plane mechanisms of the façade (mechanism 3)

- Transversal response of the nave (mechanism 5)

- Longitudinal response of the lateral wall, in-plane (mechanism 6)

- Triumphal arches (mechanism 13) 
- Overturning of the apse (mechanism 16)

- Shear mechanism of the aps (mechanism 17)

- Vaults of the aps (mechanism 18)

- Mechanism of the element of the roof-lateral walls of the nave (mechanism 19)

- Interaction with annexed buildings (mechanism 25)

- Bell tower (mechanism 27)

- Upper portion of the bell tower (mechanism 28)

Figure 10 shows the activated mechanisms and the relative damage, reported by the team of surveyors. This interpretation, made for each macro-element, leads to elaborate the general damage index of the church $\left(\mathrm{I}_{\mathrm{d}}\right)$; in this case, the reported value is equal to 0.32 [52].

Damage 1

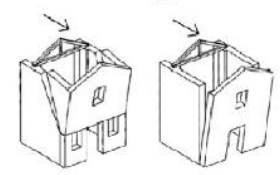

Level of damage

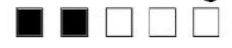

(a)

Damage 17

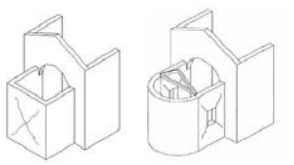

Level of damage

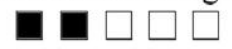

(e)
Damage 2

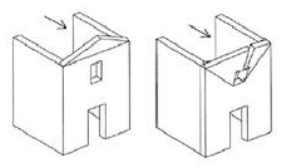

Level of damage

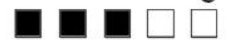

(b)

Damage 18

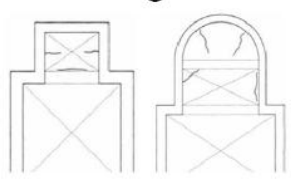

Level of damage

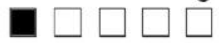

(f)
Damage 3

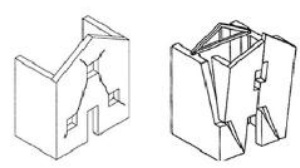

Level of damage

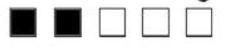

(c)

Damage 27

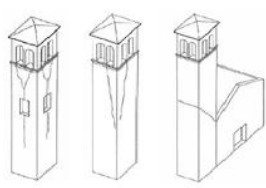

Level of damage

(g)

Damage 5

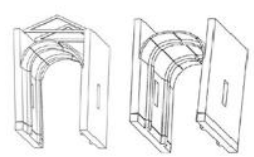

Level of damage

(d)

Damage 28

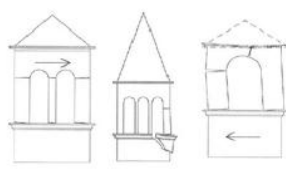

Level of damage

ㅁㅁ

(h)

Figure 10. Activated mechanisms and level of damage. Source data: [52]. (a) Overturning of the façade; (b) mechanisms of the upper part of the façade; (c) in-plane mechanisms of the façade; (d) longitudinal response of the lateral wall, in plane; (e) shear mechanism of the aps; (f) vaults of the aps; ( $g$ ) bell tower;

(h) upper portion of the bell tower.

As a result of the survey, the church was declared inaccessible [52]. Some of the mechanisms, in the church façade and in the bell tower, that occurred in the apse area have a serious or rather diffused damage. To these aspects could be associated with the given assessment of accessibility.

\subsection{Two Earthquake Episodes in Comparison: the 1997 Umbria-Marche Earthquake and the 2016 Central Italy Earthquake}

The seismicity of the area of Serravalle di Chienti is well known, as pointed out in Section 2.1. The major recent events, which hit this area and are discussed in the present work, are the 1997 Umbria-Marche and the 2016 Central Italy earthquakes. St. Salvatore Church suffered damage in both cases, even if at different levels, as is clearly visible looking at the infographic documentation. Understanding what happened from a seismic territorial perspective is one of the essential steps for the comprehension of the state of damage in the analyzed case study. Indeed, a territorial overview, together with building-scale photographic documentation, allows a deeper comprehension of the state of damage. 


\subsubsection{The 1997 Umbria-Marche Earthquake}

In the first days of September 1997, close to Colfiorito, an incremental seismic phenomenon was registered. On 26 September 1997 at 0:33 a.m., the first shock was felt with a 5.70 moment magnitude (Mw) (Figure 11a) at $3.51 \mathrm{~km}$ of depth, with the epicenter located at 43.022 latitude and 12.891 longitude [53]. After some hours, at 9:40 a.m., another strong shock (Figure 11b), with $6.01 \mathrm{Mw}$ and at $9.87 \mathrm{~km}$ of depth, hit the area with the epicenter slightly to the north (43.014 lat. and 12.853 long.) [54]. Then, on 14 October 1997 at 3:23 p.m., a shock (Figure 11c) of $5.65 \mathrm{Mw}$ at $7.33 \mathrm{~km}$ of depth hit Sellano, with the epicenter at 42.898 latitude and 12.898 longitude [55]. Other shocks followed until the first months of 1998, as is visible in the historical catalogue of seismicity of Serravalle di Chienti (Table 1). All the epicenters of the main shocks belong to the Colfiorito seismogenic unit, indicated with the number 31 in Figure $3 b$.

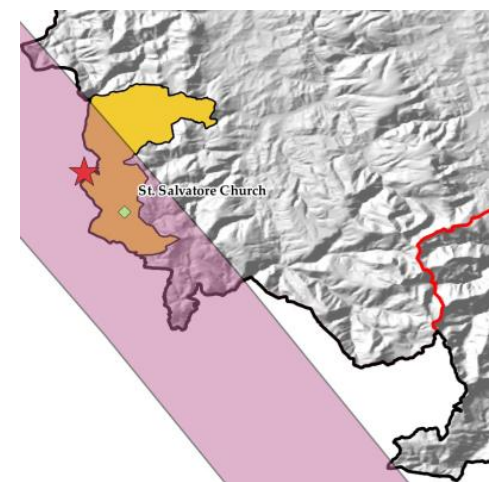

(a)

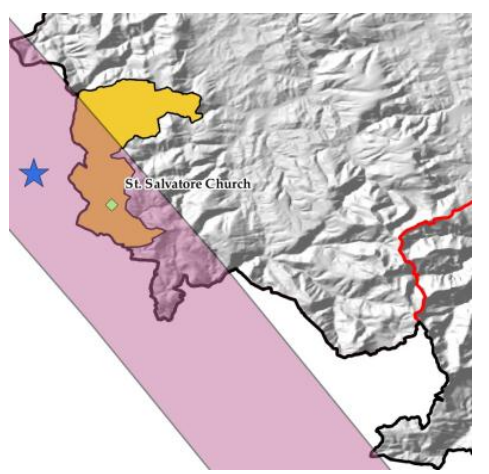

(b)

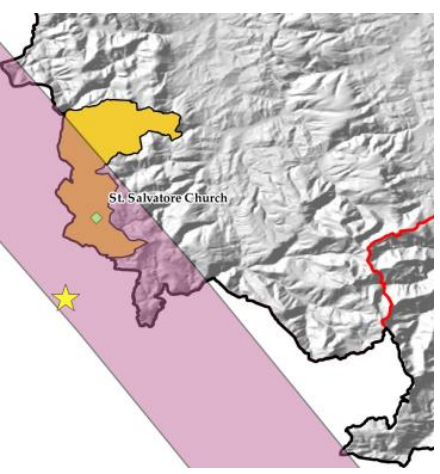

(c)

Figure 11. The 1997 major shocks with the location of St. Salvatore church (green square) in Acquapagana and the seismogenic fault system of Colfiorito (purple area). (a) The red star points out the epicenter of the 26 September 1997 event at 0:33 a.m. [53]; (b) the blue star specifies the epicenter of the 26 September 1997 event at 9:40 a.m. [54]; (c) the yellow star indicates the epicenter of the 14 October 1997 event [55].

After this series of shocks, the church suffered severe damage, as the collected images document. The south portion of the complex collapsed, while the upper part of the bell tower was strongly affected, losing portions of walls (Figure 12) in correspondence to the opening, probably due to the good connection of the transversal walls, which determined the migration of the damage in the weakest and unbound part of the structure.

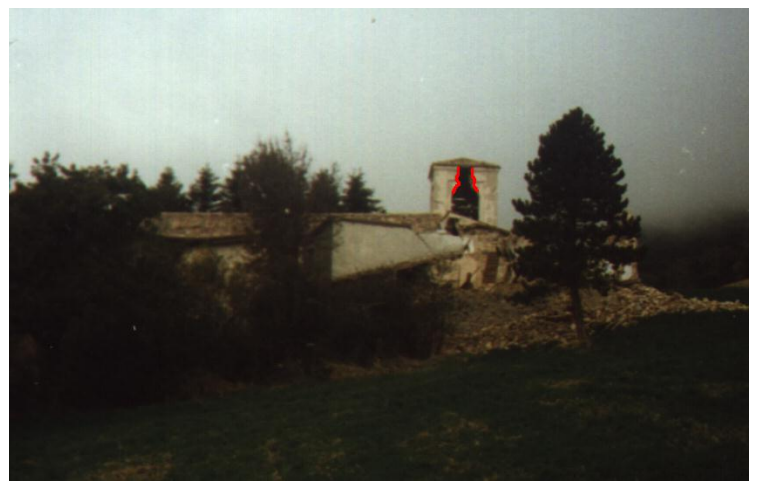

Figure 12. The image shows the state of damage post the 1997 earthquake of the east side of the building. In the foreground, the portion of the collapsed monastic complex is visible, while in the background, the damaged bell tower appears [56]. 
As mentioned in Section 2.2, the connection between lateral walls of the nave and the façade is well realized (see the image of the corner in Table 2). This aspect influences the response of the building against horizontal forces, developing a box-like behavior. Indeed, the collapse of lateral walls is located in the upper area, in contact with the roof. In this regard, the information about the substitution of the roof in the 1960s helps to understand the damage. Under seismic cycles, the concrete roof pounded on the masonry walls, causing local damage. The correlated state of damage is clearly visible in the upper part of the lateral walls (north and south) and of the buttresses (Figure 13a). Moreover, the multi-leaf walls, shaken and pounded, show the separation of the external leaf from the standing interior one. This phenomenon is visible both in the north walls (Figure 13b) and in the gable part of the main façade (Figure 13c). As in the case of the north wall, in the portion above the rose window in contact with the roof, the pounding effect caused the loss of a part of the masonry. In Figure 13c, this is visible as rubble on the ground in front of the church. The main façade also showed in-plane shear cracks in the area, which goes from the gable to the lower south west corner. These kinds of cracks followed the path of the mortar, denouncing the lower strength capacity of the mortar compared to that of the masonry. Moreover, none of the cracks cross the blocks of stone, confirming the good quality of the masonry evaluated in Section 2.2.

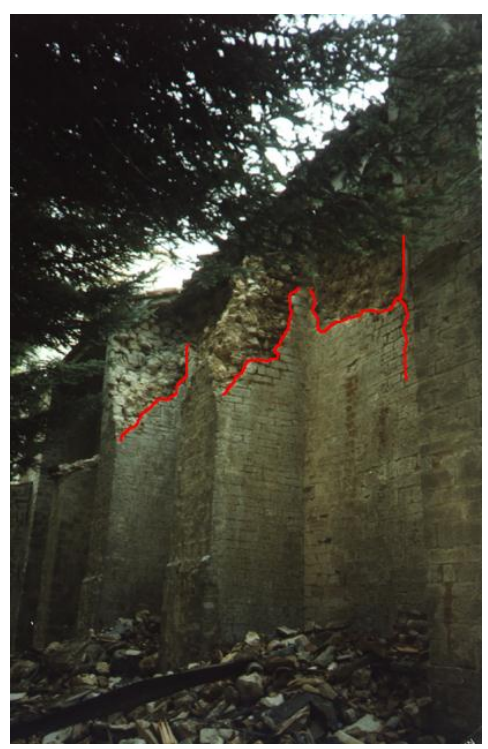

(a)

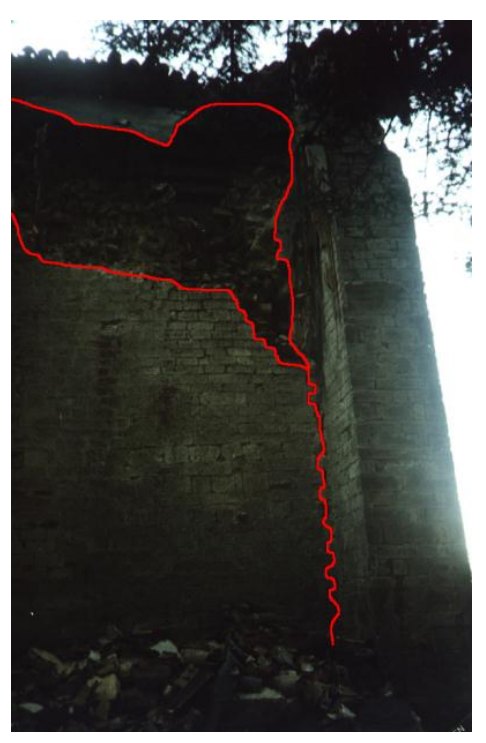

(b)

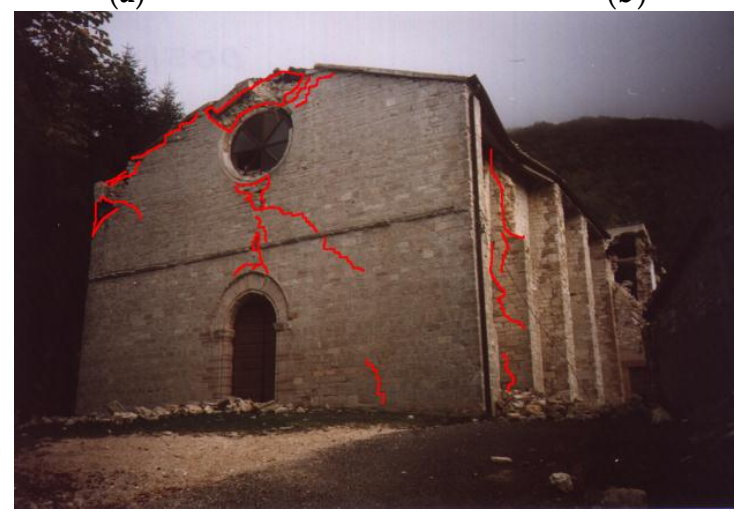

(c)

Figure 13. Post-1997 earthquake damage of the exterior of the church. Photo source [56]. (a) Collapse of the upper part of the buttresses and of the lateral walls; (b) partial collapse of the north wall of St. Salvatore church; (c) damaged gable, left portion of the upper side of the façade, shear crack in the central part under the rose window and collapse of the upper portion of the buttresses of the south side. 
Finally, the damage also occurred the interior of the church. The stiffness of the concrete roof determined shear cracks in the triumphal masonry arches, as shown in Figure 14a. Furthermore, from the images of the church interior, the loss of both the internal leaf of the façade wall and of part of the upper portion of the lateral walls (Figure 14b) is visible. The explanation of this damage is the same as the exterior damage.

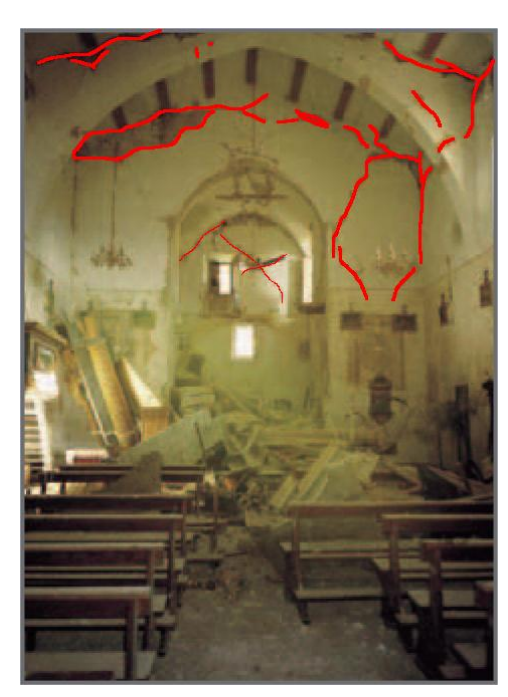

(a)

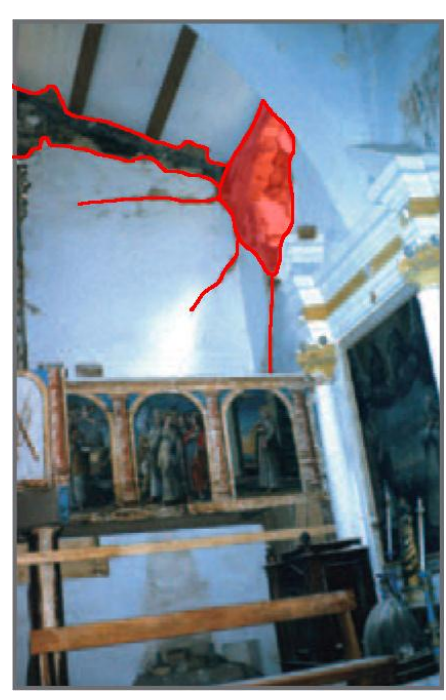

(b)

Figure 14. Post-1997 earthquake damage of the interior of the church. Photo source: [57]. (a) View of the triumphal arches towards the apse area. Diffuse shear cracks and pounding damage. (b) Inside view of St. Salvatore church. Partial collapse of the wall and of part of the internal leaf of the wall of the main façade at the tympanum level.

\subsubsection{The 2016 Central Italy Earthquake}

Acquapagana in Serravalle di Chienti is among the areas hit by the several shocks that have affected Central Italy since August 2016. The major shocks happened on 24 August 2016, on 26 and 30 October 2016 and on 18 January 2017. The I.N.G.V. (Istituto Nazionale di Geofisica e Vulcanologia) identifies these events with the so-called Amatrice-Norcia-Visso seismic sequence. Maps in Figure 15 show the PGA curves for each seismic event together with the church location. For the series of shocks, other data, such as the shake maps, could be found in [58-61]. 


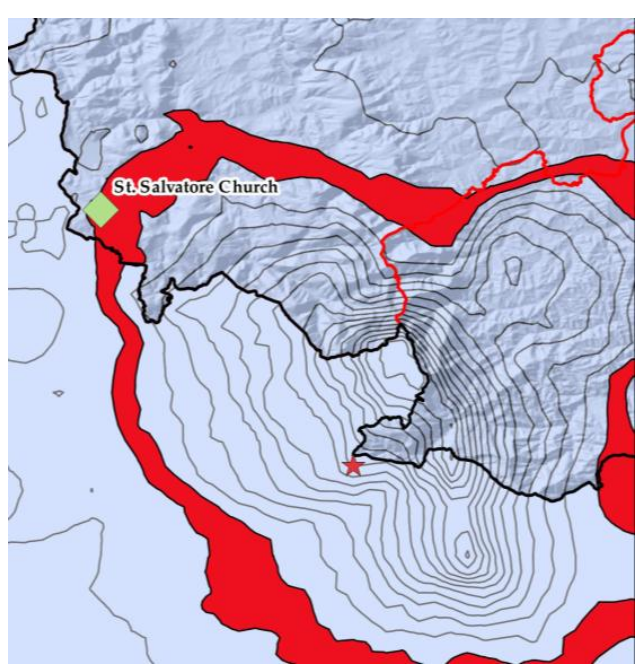

(a)

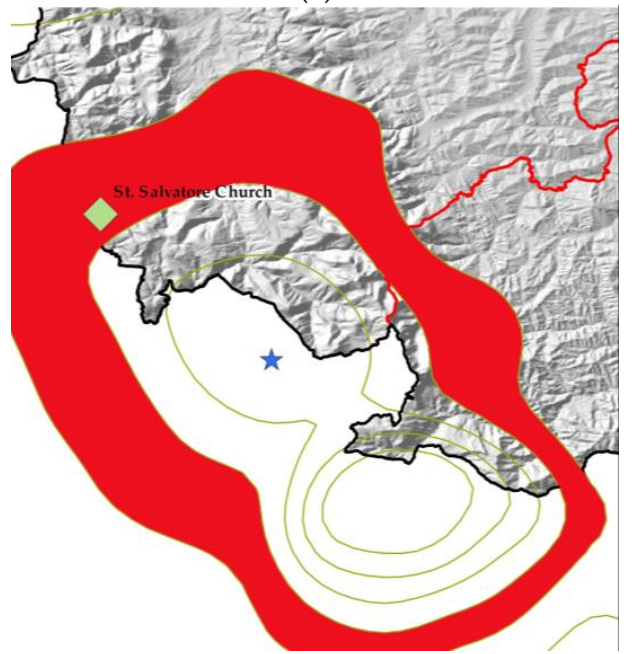

(c)

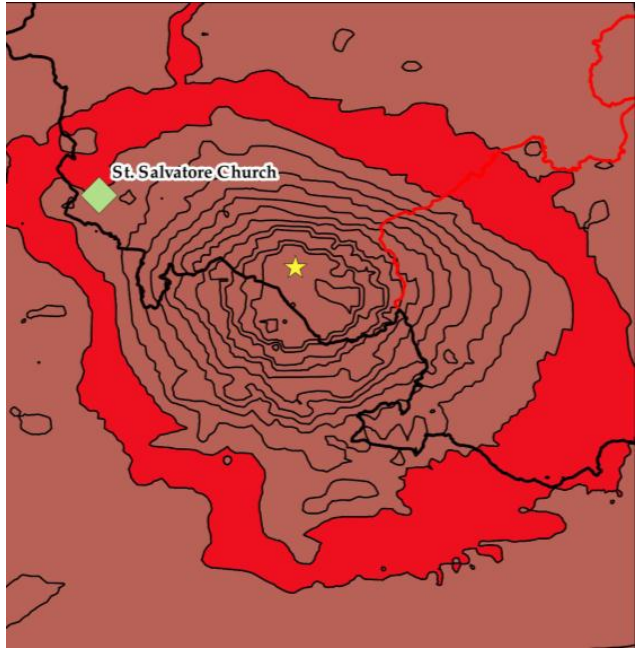

(b)

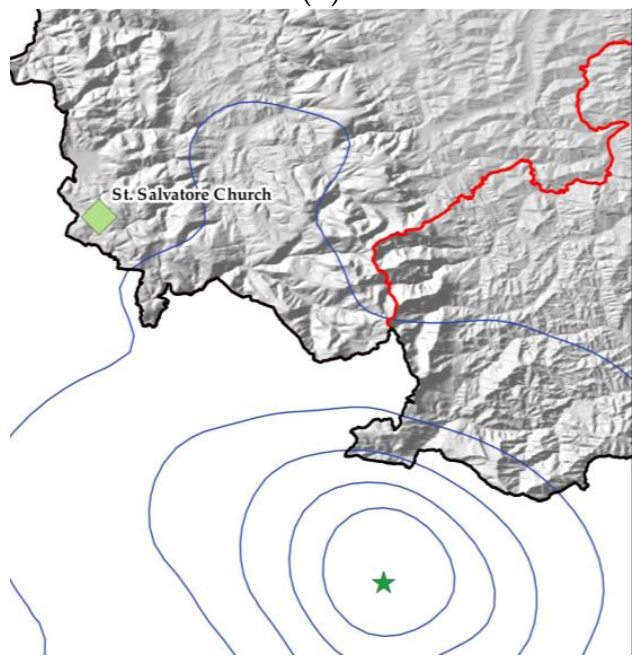

(d)

Figure 15. PGA isocurves of the main shocks. (a) Event of 24 August (12\% g); the epicenter is the red star [58]; (b) event of 26 October ( $8 \%$ g); the epicenter is the yellow star [59]; (c) event of 30 October $(12 \% \mathrm{~g})$; the epicenter is the blue star [60]; (d) Event of 18 January $(2.5 \% \mathrm{~g})$; the epicenter is the green star [61].

These maps are the result of a QGIS software [62] elaboration: the overlapping of geographical information-St. Salvatore Church coordinates $\left(42^{\circ} 59^{\prime} 00.5^{\prime \prime} \mathrm{N} 12^{\circ} 55^{\prime} 49.2^{\prime \prime} \mathrm{E}\right)$ and administrative limits-with the curves of the PGA ( $\% \mathrm{~g})$ allows one, for each seismic event, to connect different kinds of information. Even if a more specific assessment would require the acceleration time history at the site, this step of knowledge is helpful for the comprehension of what happened in those areas. Indeed, these maps show that, on 24 August, the church reached a PGA curve of $12 \% \mathrm{~g}$ (Figure 15a), on the 26 October of $8 \%$ of g. (Figure 15b), on 30 October of $12 \%$ of g (Figure 15c), while, on 18 January, the church is outside the curve of $2.5 \%$ of $\mathrm{g}$ (Figure $15 \mathrm{~d}$ ). Even if in this last case, the PGA value is lower than in the preceding shocks, the church structure could have suffered damage because it was already compromised. In this regard, $[63,64]$ could contribute to explaining the progression of damage caused by the repetitive shocks. Moreover, all the values stay in the range of the expected acceleration of the area, specified in Section 2.1.

The effects of the 2016 earthquake on the building have been studied according to: the onsite external survey, the collection of photographic documentation related to the moment before the provisional interventions and the survey form [52] of St. Salvatore filled out by a ReLUIS (Rete 
Laboratori Universitari di Ingegneria Sismica) team after the 2016 earthquake. Both the bell tower and the church building present a significant state of damage. Externally, in particular on the east side, the bell tower appears compromised: along the height, shear cracks are present; due to the plaster, it is not possible to affirm that the cracks follow the mortar. Probably the path of the cracks, at some points, provides evidence of the discontinuity of the masonry caused by reconstruction after seismic events (Figure 16a,b). This is visible in the upper part of the bell tower. Indeed, Figure 12 confirms that this portion was rebuilt after the 1997 earthquake. Moreover, the upper part of the bell tower, on the west side, shows not only shear cracks, but also torsional ones (Figure 16c). The presence of the tie rods efficiently works: indeed, this portion of the tower reacts with a box-like behavior effect, providing a contrast to the torsional action and causing cracks at the base of the terminal part of the bell tower. Figure 16d shows a diagonal and vertical crack that should be connected to the pounding effect between the annexed body and the buttress of the nave, which shows Mechanism 5 (see Section 2.3).

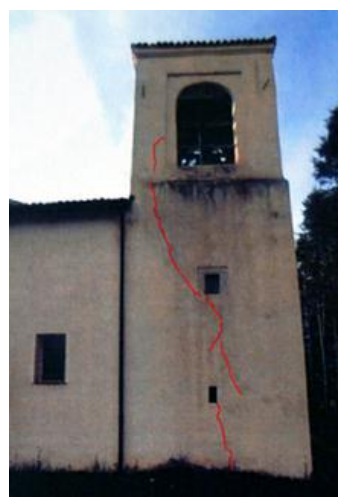

(a)

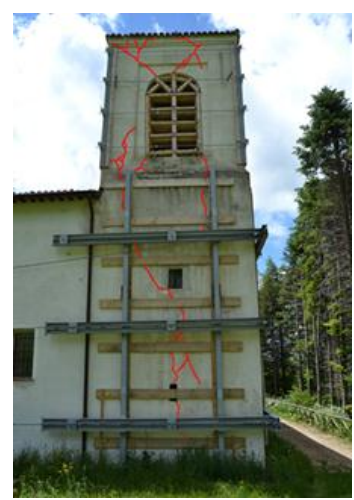

(b)

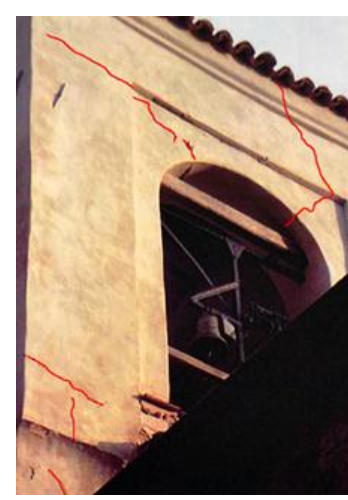

(c)

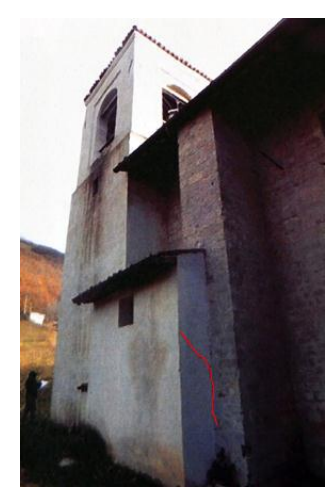

(d)

Figure 16. Exterior post-2016 earthquake damage. (a) Shear cracks along the height of the bell tower [47]; (b) damaged bell tower with provisional interventions; (c) torsional and shear cracks [47]; (d) diagonal and vertical crack in the annexed building in contact with the buttress of the north wall of the nave [47].

The state of damage observed outside has a correspondence with the interior part of the bell tower, where the cracks cross the different levels of the structure (Figures 16c and 17a,b).

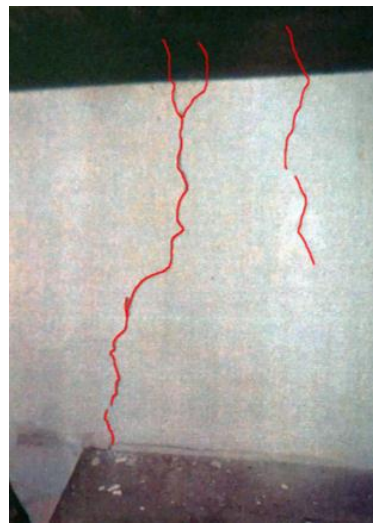

(a)

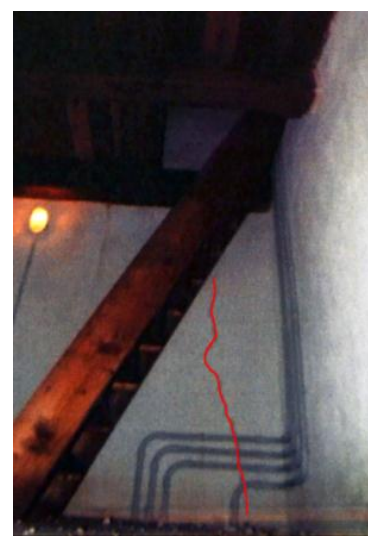

(b)

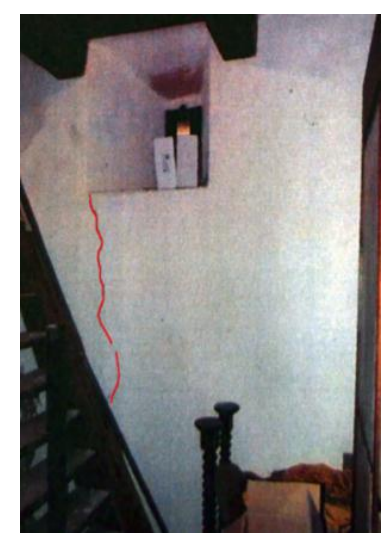

(c)

Figure 17. Interior state of damage of the bell tower. (a) Shear cracks of the ground floor [47]; (b) continuous part of the shear crack of the first floor [47]; (c) shear crack on the north side [47]. 
The damage of the church building appeared more concentrated in the principal façade. Indeed, from external images (Figure 18), the façade shows light visible lesions in correspondence with the timber beam of the roof, which causes shear cracks because of the pounding effect. Light lines of damage are present, retracing the discontinuity of the masonry due to the post-1997 earthquake reconstruction of the gable of the façade.

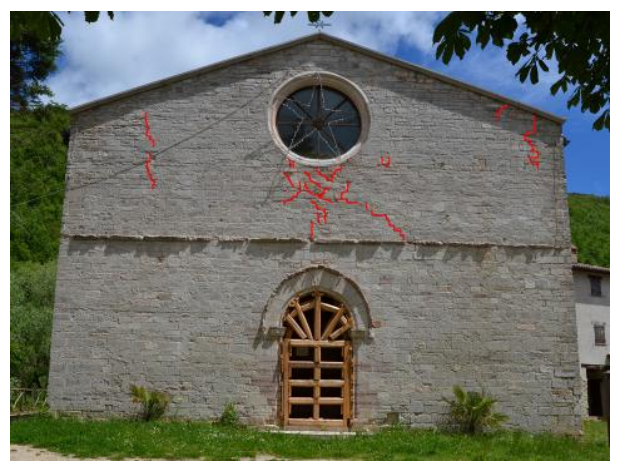

Figure 18. Post-2016 earthquake damage of the external façade with the damage pattern.

The pounding effect of the timber beams of the roof, introduced post-1997 earthquake, is more evident from the interior of the church (Figure 19a). The overturning mechanism of the façade is shown in Figure 19b. A vertical line of discontinuity denounces the overturning of the façade, evaluated in Figure 10, underlined also by the diagonal cracks in the lateral walls.

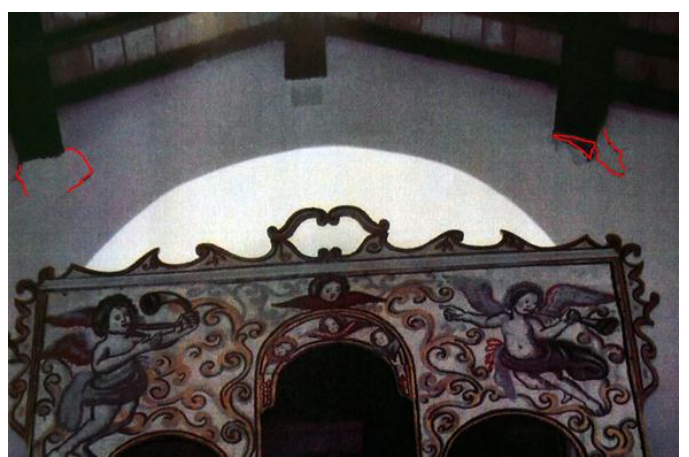

(a)

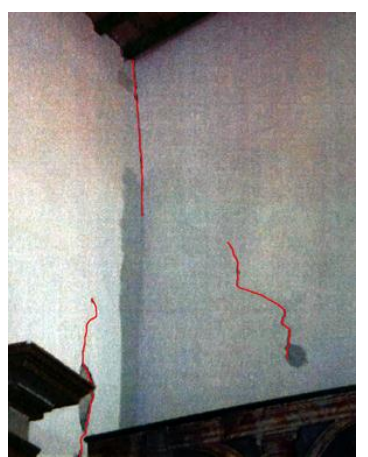

(b)

Figure 19. Post-2016 earthquake damage of the inside view of the west wall of the church. (a) Cracks at the intersection between the beams of the roof and the facade [47]; (b) vertical crack between the façade and the lateral wall where there are also diagonal cracks [47].

\section{Discussion}

The multidisciplinary approach, exemplified in this article, for the assessment of the state of damage has provided a more exhaustive vision, not limited to the building scale. Several aspects have been considered, as summarized in Figure 1. Information on the seismogenic source systems, on the PGA accelerations, on the localization of the epicenters, archived data of the historical seismicity of the area, the documentation of the state of damage from the survey form used for churches and images of the state of damage have been employed.

The comparison between the two seismic episodes, the 1997 Umbria-Marche and 2016 Central Italy earthquake, shows a milder state of damage in the last one. In summary, this could be caused by: (a) a lower distance from the epicenters of the several shocks in the 1997 Umbria-Marche earthquake compared to those of the 2016 Central Italy earthquake (Figure 20); (b) the different propagation 
direction of waves, from the northwest (26 and 27 September) and from the south (14 October) in the 1997 earthquake, while southeast/east in the 2016 earthquake, in reference to the position of the church explained in Section 2.1 and in Figure 2c, as well as the effectiveness of the interventions done after the 1997 earthquake.

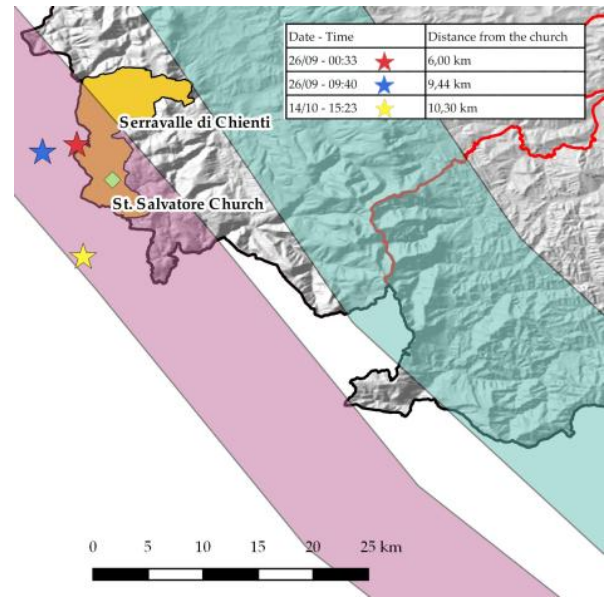

(a)

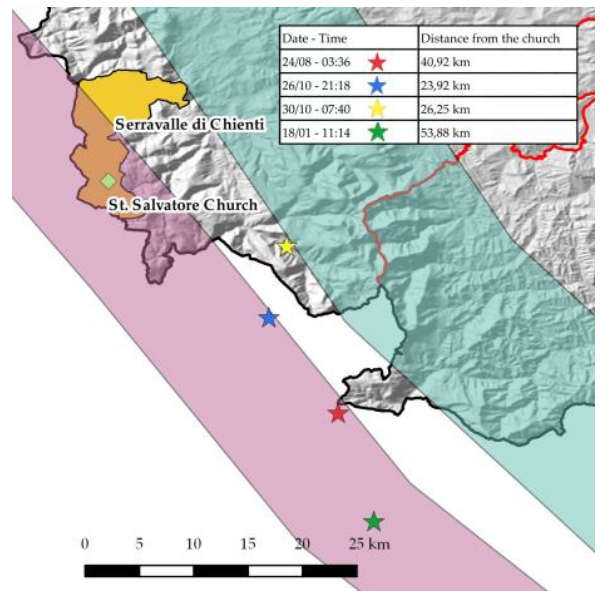

(b)

Figure 20. Maps showing the distances of epicenters of the principal shocks from the church. (a) The map presents the 1997 Umbria-Marche earthquake shocks. Data source: [41,53-55]. (b) This map shows the 2016 Central Italy earthquake shocks. Data source: [41,58-61].

At the building scale, from the comparison of the state of damage between the two earthquakes, some considerations can be made. Observing Figure 21, the shear cracks on the plane of the façade, below the rose window are lightly marked from the recent earthquake.

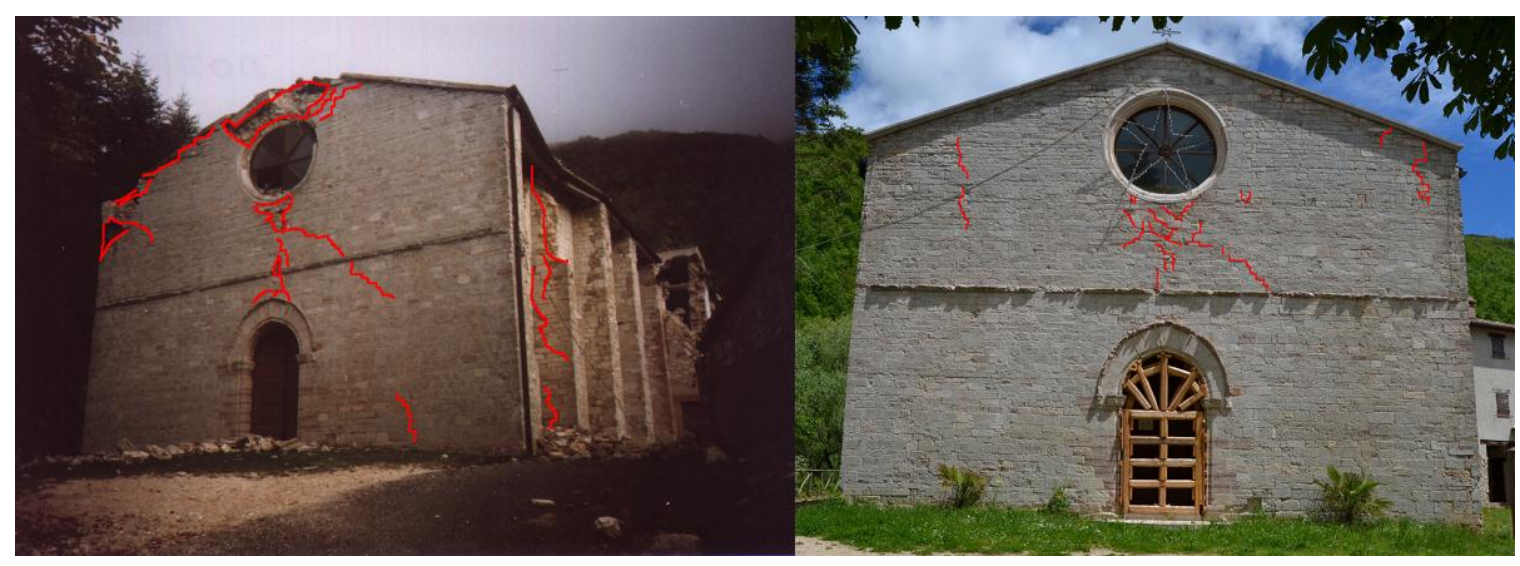

Figure 21. Comparison of the state of damage on the façade after the 1997 earthquake (on the left) and the 2016 one (on the right).

On the contrary, the upper portion of the gable, in contact with the roof, is in good condition, and it does not show the separation of the leaves. It seems that a good interlocking between the internal and the external leaf of the façade has been performed with the post-1997 earthquake intervention. Moreover, the substitution of the heavy concrete roof with a light timber structure (Figure 22) has contributed to reducing the mass, which during the cyclic dynamic effects of the earthquake, could have severely damaged the façade. 


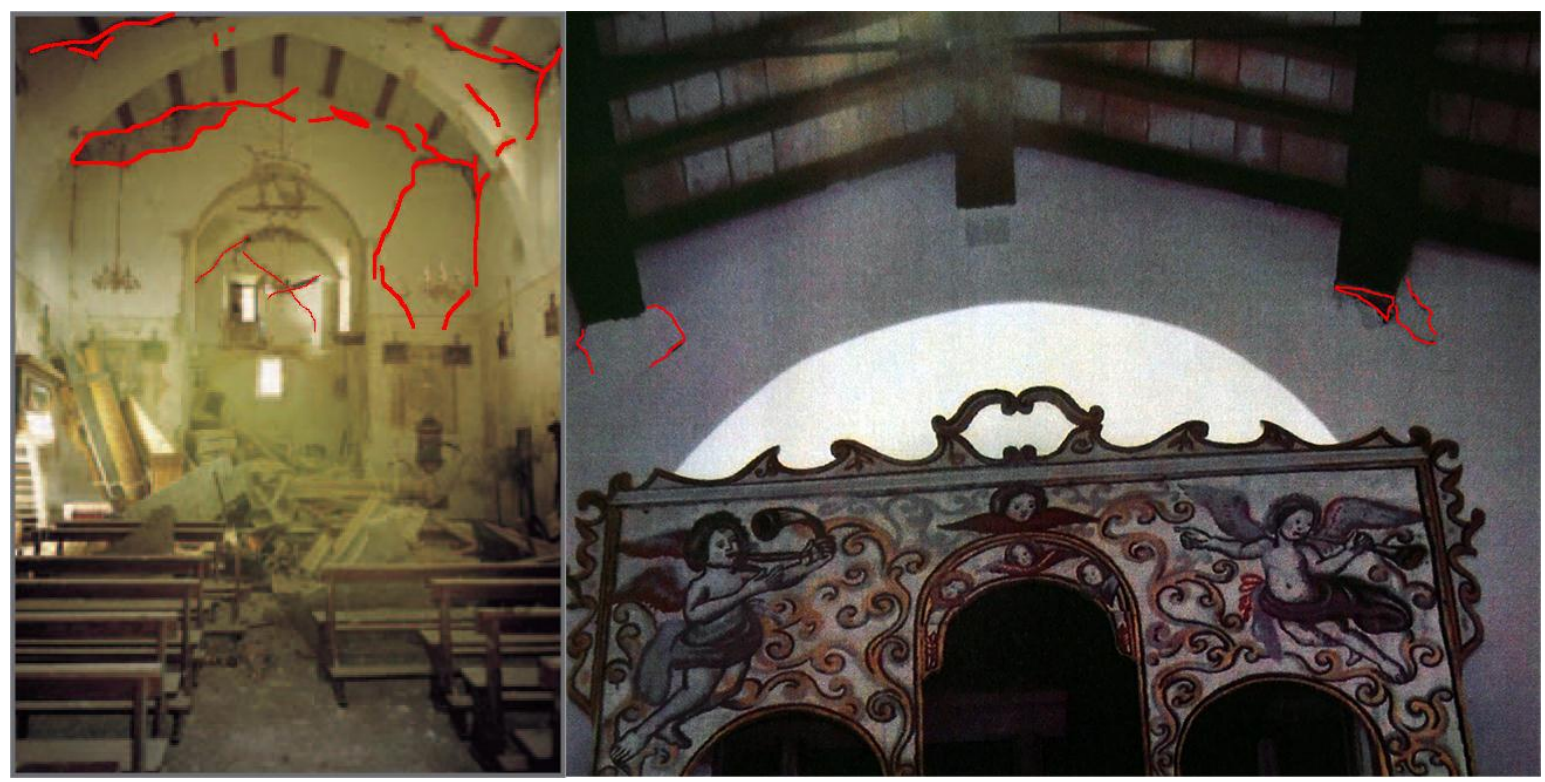

Figure 22. Comparison of the types of roof and the relative state of damage after the 1997 earthquake and the 2016 one.

The effectiveness of these interventions seems to be demonstrated, even if further studies should be done in this regard. An improvement in the connection between the timber beams and the wall is recommended. A good box-like effect of the building was observed in both events. Nevertheless, the rather high level of damage of Mechanisms 1 and 2 (Figure 10) suggests the use of tie rods at the level of the gable, in correspondence with the transversal walls. In the case of the bell tower, the tie rods helped to keep the four walls together and to limit the damage. The interventions performed on the main façade, on the lateral masonry walls and on the buttresses have provided good seismic performance.

Finally, other general considerations can be added:

- In the bell tower, an additional steel structure, tying together the four walls of the bell tower, could guarantee ductility and reduce torsional movement of the upper portion.

- The existing independent steel structure, used to carry the bells, has shown a satisfactory response to seismic actions and probably has reduced the damage to the masonry structure.

\section{Conclusions}

The multidisciplinary procedure for the assessment of seismic damage, presented in this work, demonstrates the advantages that such an approach can provide in terms of a more exhaustive vision of the damage.

This methodology could be applied to other churches recently affected by earthquakes in Central Italy and to other similar situations, thanks to its replicability and adaptability. Indeed, inserting churches with their own coordinates in a GIS work space, together with seismic data of an earthquake, accessible from the INGV website [65] or in general from similar authorities, the damage of the building can be studied; moreover, seismic accelerations, directions and distances can be considered. In keeping with such an approach, a knowledge of the territorial scenario could be achieved, in terms both of the vulnerability of the geographical area and of the interventions performed after seismic events. Meanwhile, this methodology for the assessment of damage could help to store and collect territorialand building-scale information, which would be useful for future advancement of knowledge. 
Acknowledgments: The valuable help of Floriana Pergalani, Claudio Chesi and Maria Adelaide Parisi (Politecnico di Milano), of the Assessore Pietro Ricci and of the Municipality of Serravalle di Chienti, is gratefully acknowledged. The research was partially supported by the ReLUIS-DPC Project 2017.

Author Contributions: Both authors are responsible of the whole article. Gessica Sferrazza Papa, mostly, contributed on the territorial, structural and damage analysis; while, Benedetta Silva on the historical and material investigation.

Conflicts of Interest: The authors declare no conflicts of interest.

\section{References}

1. Form A-DC PCM-DPC MIBAC. 2006. Available online: http://www.beniculturali.it/mibac/multimedia/ MiBAC/documents/1338454237471_allegato4.pdf (accessed on 1 September 2017).

2. Doglioni, F.; Moretti, A.; Petrini, V. Le Chiese e il Terremoto; LINT Press: Trieste, Italy, 1994; ISBN 8886179367.

3. Lagomarsino, S. Seismic damage survey of the churches in Umbria. In Proceedings of the Workshop on Seismic Performance of Monuments, Lisbon, Portugal, 12-14 November 1998.

4. Doglioni, F.; Mazzotti, P. Codice di Pratica per la Progettazione Degli Interventi di Miglioramento Sismico nel Restauro del Patrimonio Architettonico, 2nd ed.; Regione Marche: Ancona, Italy, 2007; ISBN 978-88-902669-0-4.

5. Giovanetti, F. Manuale di Recupero. Città di Roma; Edizioni DEI; Tipografia del Genio Civile: Roma, Italy, 1997; ISBN 88-7722-552-1.

6. Giovanetti, F. Manuale del Recupero del Comune di Città di Castello; Edizioni DEI; Tipografia del Genio Civile: Roma, Italy, 1997; 239p, ISBN 9788849652260.

7. Giuffrè, A.; Carocci, C. Codice di Pratica per la Conservazione dei Sassi di Matera; Edizioni La Bautta: Matera, Italy, 1997; 302p, ISBN 9788885425361.

8. Giuffrè, A.; Carocci, C. Codice di Pratica per la Sicurezza e la Conservazione del Centro Storico di Palermo; Laterza: Bari, Italy, 1999; 200p, ISBN 88-420-5687-1.

9. Guerrieri, F. Regione Umbria. Manuale per la Riabilitazione e Ricostruzione Post Sismica Degli Edifici; Edizioni DEI; Tipografia del Genio Civile: Roma, Italy, 1999; 591p, ISBN 88-496-0851-9.

10. Cangi, G. Manuale Recupero Antisismico; Edizioni DEI; Tipografia del Genio Civile: Roma, Italy, 2005; ISBN 88-496-1421-7.

11. Angeletti, P.; Ferrini, M.; Lagomarsino, S. Survey and evaluation of the seismic vulnerability of the churches: An application in Lunigiana and Garfagnana. In Proceedings of the Associazione Nazionale Italiana Di Ingegneria Sismica, 8th Italian National Conference on Earthquake Engineering, Taormina, Italy, 20-24 September 1997.

12. Tobriner, S.; Comerio, M.; Green, M. Reconnaissance Report on the Umbria-Marche, Italy, Earthquakes of 1997. EERI Special Earthquake Report. December 1997, pp. 1-12. Available online: https:/ /www.eeri.org/lfe/ pdf/Italy_Umbria_Marche_Insert_Dec97.pdf (accessed on 1 November 2017).

13. Lagomarsino, S.; Podestà, S. Seismic vulnerability of ancient churches: I. Damage assessment and emergency planning. Earthq. Spectra 2004, 20, 377-394. [CrossRef]

14. Lagomarsino, S.; Podestà, S. Damage and vulnerability assessment of Churches after the 2002 Molise, Italy, Earthquake. Earthq. Spectra 2004, 20, S271-S283. [CrossRef]

15. Da Porto, F.; Silva, B.; Costa, C.; Modena, C. Macro-scale analysis of damage to churches after earthquake in Abruzzo (Italy) on April 6, 2009. J. Earthq. Eng. 2012, 16, 739-758. [CrossRef]

16. Modena, C.; Binda, L. Monumental historical buildings. Protection of the cultural heritage in the post-earthquake emergency. Progettazione Sismica 2009, 3, 107-115.

17. Kaplan, H.; Bilgin, H.; Yilmaz, S.; Binici, H.; Oztas, A. Structural damages of L'Aquila Earthquake (2009). Nat. Hazards Earth Syst. Sci. 2010, 10, 499-507. [CrossRef]

18. Lagomarsino, S. Damage assessment of churches after L'Aquila earthquake (2009). Bull. Earthq. Eng. 2012, 10, 73-92. [CrossRef]

19. Brandonisio, G.; Lucibello, G.; Mele, E.; De Luca, A. Damage and performance evaluation of masonry churces in the 2009 L'Aquila earthquake. Eng. Fail. Anal. 2013, 34, 693-714. [CrossRef]

20. De Matteis, G.; Criber, E.; Brando, G. Damage probability matrices for three-nave masonry churches in Abruzzi after the 2009 L'Aquila earthquake. Int. J. Archit. Herit. 2015, 10, 120-145. 
21. Krstevska, L.; Tashkov, L.; Naumovski, N.; Florio, G.; Formisano, A.; Fornaro, A.; Landolfo, R. In situ experimental testing of four historical buildings damaged during the 2009 L'Aquila earthquake. In Proceedings of the Cost Action C26 Final Conference "Urban Habitat Constructions under Catastrophic Events", Naples, Italy, 16-18 September 2010; pp. 427-432.

22. Sorrentino, L.; Liberatore, L.; Decanini, L.D.; Liberatore, D. The performance of churches in the 2012 Emilia earthquakes. Bull. Earthq. Eng. 2014, 12, 2299-2331. [CrossRef]

23. Indirli, M.; Marghella, G.; Marzo, A. Damage and collapse mechanisms in churches durign the Pianura Padana Emiliana earthquake. EAI 2012, 4-5, 69-94.

24. Clementi, F.; Quagliarini, E.; Monni, F.; Giordano, E.; Lenci, S. Cultural heritage and earthquake: The case study of 'Santa Maria della Carità' in Ascoli Piceno. Open Civ. Eng. J. 2017, 11, 1079-1105. [CrossRef]

25. Lancioni, G.; Piattoni, Q.; Lenci, S.; Quagliarini, E. Dynamics and failure mechanisms of ancient masonry churches subjected to seismic actions by using the NSCD method: The case of the medieval church of S. Maria in Portuno. Eng. Struct. 2013, 56, 1527-1546. [CrossRef]

26. Milani, G.; Valente, M. Comparatiove pushover and limit analyses on seven masonry churches damaged by the 2012 Emilia-Romagna (Italy) seismic events: Possibilities of non-linear Finite Elements compared with pre-assigned failure mechanisms. Eng. Fail. Anal. 2015, 47, 129-161. [CrossRef]

27. Cundari, A.; Milani, G.; Failla, G. Seismic vulnerability evaluation of historical masonry churches: Proposal for a general and comprehensive numerical approach to cross-check results. Eng. Fail. Anal. 2017, 82, 208-228. [CrossRef]

28. Formisano, A.; Ciccone, G.; Mele, A. Large scale seismic vulnerability and risk evaluation of a masonry churces sample in the historical centre of Naples. In Proceedings of the 13th International Conference of Computational Methods in Sciences and Engineering (ICCMSE 2017), Thessaloniki, Greece, 21-25 April 2017.

29. Linee Guida per la Valutazione e Riduzione del Rischio Sismico del Patrimonio Culturale Allineate alle Nuove Norme Tecniche per le Costruzioni (D.M. 14 Gennaio 2008). Available online: http:/ / www.beniculturali.it/ mibac/multimedia/MiBAC/documents/1295444865088_LINEE.pdf (accessed on 01 September 2017).

30. NTC 2008. Decreto Ministeriale delle Infrastrutture 14 Gennaio 2008. Approvazione Delle Nuove Norme Tecniche per le Costruzioni. 2008. Available online: http://www.ca.archiworld.it/normativa/italia/ NORME_TECNICHE/DM_14_01_2008.PDF (accessed on 3 December 2017).

31. ICOMOS Charter. Principles for the analysis, conservation and structural restoration of architectural heritage; International council on monumental and sites(ICOMOS). In Proceedings of the 14th ICOMOS General Assembly, Victoria Falls, Zimbabwe, Harare, Zimbabwe, 27-31 October 2003; Available online: https:/ / www.icomos.org/charters/structures_e.pdf (accessed on 24 October 2017).

32. Savorra, M.; Fabbrocino, G.; Marra, A. Un approccio multidisciplinare per la conoscenza dei beni architettonici: Il caso della Certosa di Trisulti. In La Baia di Napoli. Strategie Integrate per la Conservazione e la Fruizione del Paesaggio Culturale; Aveta, A., Marino, B.G., Amore, R., Eds.; Artstudio Paparo: Naples, Italy, 2017.

33. Ranieri, C.; Marra, A.; Ranieri, G.M.; Gargaro, D.; Pepe, M.; Fabbrocino, G. Integratednon-descructive assessment of relevant structural elements of an Italina heritage site: The Carthusian monastery of Trisulti. J. Phys. Conf. Ser. 2015, 628, 012018. [CrossRef]

34. Marra, A. Il complesso monumentale di Santa Chiara a Napoli: Un modello innovative per la conoscenza e la valorizzazione. In Conoscere, Conservare, Valorizzare il Patrimonio Religioso; Niglio, O., Visentin, C., Eds.; ARACNE Editore: Rome, Italy, 2017; Volume 3.

35. MiBACT. Codice dei Beni Culturali e del Paesaggio ai Sensi dell'Articolo 10 Legge 6 Luglio 2002, n. 137 (D.L. 22 Gennaio 2004, n. 42). Available online: www.unesco.beniculturali.it/getFile.php?id=226 (accessed on 24 October 2017).

36. Carbonari, S.; Catanzaro, A.; D’Agostino, V.; Dall'Asta, V.; Dezi, L.; Gara, F.; Leoni, G.; Morici, M.; Prota, A.; Zona, A. Prime analisi e considerazioni circa di danni rilevati al patrimonio culturale delle marche a valle del terremoto del Centro Italia (2016). In Proceedings of the Associazione Nazionale Italiana Di Ingegneria Sismica 2017, XVII Convegno L'Ingegneria sismica in Italia, Pistoia, Italy, 17-21 September 2017.

37. De Matteis, G.; Zizi, M.; Corlito, V. Analisi preliminare degli effetti del terremoto del Centro italia del 2016 sulle chiese a una navata. In Proceedings of the Associazione Nazionale Italiana Di Ingegneria Sismica 2017, XVII Convegno L'Ingegneria sismica in Italia, Pistoia, Italy, 17-21 September 2017. 
38. Lagomarsino, S.; Podestà, S. Seismic vulnerabilty of ancient churches: II. statistic analysis of surveyed data and methods for risk analysis. Earthq. Spectra 2004, 20, 395-412. [CrossRef]

39. Lourenço, P.B.; Roque, J.A. Simplified indexes for the seismic vulnerability of ancient masonry buildings. Constr. Build. Mater. 2006, 20, 200-208. [CrossRef]

40. Aerial View. Available online: https:/ / maps.google.com/ (accessed on 15 June 2017).

41. DISS Working Group. Database of Individual Seismogenic Sources (DISS), Version 3.2.0: A Compilation of Potential Sources for Earthquakes Larger than M 5.5 in Italy and Surrounding Areas; Istituto Nazionale di Geofisica e Vulcanologia: Roma, Italy, 2015; Available online: http:/ / diss.rm.ingv.it/diss/. [CrossRef]

42. Galadini, F.; Meletti, C.; Vittori, E. Stato delle Conoscenze Sulle Faglie Attive in Italia: Elementi Geologici di Superficie. Risultati del Progetto 5.1.2 "Inventario delle Faglie Attive e dei Terremoti ad esse Associabili" di Superficie. Available online: ftp:/ /ftp.ingv.it/pro/gndt/Pubblicazioni/Meletti/2_01_galadini.pdf (accessed on 20 November 2017).

43. Istituto Nazionale di Geofisica e Vulcanologia. Seismic Hazard Map of Marche Region. Available online: http:/ / zonesismiche.mi.ingv.it/mappa_ps_apr04/marche.html (accessed on 15 June 2017).

44. Istituto Nazionale di Geofisica e Vulcanologia-Database Macrosismico Italiano 2015. Available online: https:/ / emidius.mi.ingv.it/CPTI15-DBMI15/query_place/ (accessed on 15 June 2017).

45. Historical Description of the Monastic Complex. Available online: http://www.beniculturali.marche.it/ Ricerca.aspx?ids=69805 (accessed on 15 June 2017).

46. Tassi, C. Le chiese romaniche delle Marche dopo il sisma del 1997. In Il Sisma. Ricordare Prevenire Progetto; Fiandaca, O., Lione, R., Eds.; Alinea editrice s.r.l: Firenze, Italy, 2009; pp. 265-279, ISBN 978-88-6055-460-4.

47. Castrataro, M.; Silvestri, M. Relazione Generale sul Progetto per la Messa in Sicurezza Della Chiesa di San Salvatore-Loc. Acquapagana; Technical Report; Comune di Serravalle di Chienti: Serravalle di Chienti MC, Italy, December 2016; pp. 1-8.

48. Baila, A.; Binda, L.; Borri, A.; Cangi, G.; Cardani, G.; Castori, G.; Corradi, M.; De Maria, A.; Del Monte, E.; Donà, C.; et al. Manuale delle Murature Storiche; DEI: Rome, Italy, 2011; ISBN 978-8849604030.

49. 2003 Regolamento Regionale 15 luglio 2003, n. 9. Norme Regolamentari di Attuazione dell'Art. 5 della Legge Regionale del 23 Ottobre 2002, n. 18-Norme in Materia di Prevenzione Sismica del Patrimonio Edilizio; Bolletino Ufficiale: Perugia, Italy, 2003; p. 95.

50. Giuffrè, A. Letture Sulla Meccanica Delle Murature Storiche; Edizioni Kappa: Rome, Italy, 1991; ISBN 9788880241591.

51. Papa, S.; Di Pasquale, G. Manuale per la Compilazione Della Scheda per il Rilievo del Danno ai Beni Culturali, Chiese MODELLO A-DC. Available online: http:/ / www.awn.it/component/attachments/download/1247 (accessed on 15 June 2017).

52. Palomba, V. Form of Damage for San Salvatore Church; Technical Report; Comune di Serravalle di Chienti: Serravalle di Chienti MC, Italy, 22 February 2017; pp. 1-19.

53. Archivio Storico Macrosismico Italiano. (a) Data Relative to the 1997 Umbria-Marche Earthquake (26 September 1997-00:33). Available online: https:/ / emidius.mi.ingv.it/ASMI/event/19970926_0033_000 (accessed on 10 November 2017).

54. Archivio Storico Macrosismico Italiano. (b) Data (epicenter, Mw, depth) Relative to the 1997 Umbria-Marche Earthquake (26 September 1997-09:40). Available online: https:/ / emidius.mi.ingv.it/ASMI/event/19970926_ 0940_000 (accessed on 10 November 2017).

55. Archivio Storico Macrosismico Italiano. (c) Data (Epicenter, Mw, Depth) Relative to the 1997 Umbria-Marche Earthquake (14 October 1997-15:23). Available online: https: / emidius.mi.ingv.it/ASMI/event/19971014_ 1523_000 (accessed on 10 November 2017).

56. Archived Photo in MiBACT GIS Website. Available online: http://vincoliinretegeo.beniculturali.it/vir/vir/ vir.html (accessed on 15 June 2017).

57. Direzione Regionale per i Beni Culturali e Paesaggistici delle Marche. RiMARCANDO. 1997-2007: A 10 Anni dal Sisma, Special ed.; Tecnostampa: Loreto, Italy, 2007.

58. Istituto Nazionale di Geofisica e Vulcanologia. (a) Data of the Shock of 24 August 2016 in Central Italy. Available online: https:/ /ingvterremoti.files.wordpress.com/2016/09/relazione_di_dettaglio_rieti_ mw_6-0_del_2016-08-24_01_36_32_utc_versione_del_2016-08-24_ore_04_26_02_utc-1.pdf (accessed on 15 June 2017). 
59. Istituto Nazionale di Geofisica e Vulcanologia. (b) Data of the Shock of 26 October 2016. Available online: https:/ /ingvterremoti.files.wordpress.com/2016/10/relazione_di_dettaglio_macerata_mw_5-9_ del_2016-10-26_19_18_05_utc_versione_del_2016-10-26_ore_22_42_54_utc.pdf (accessed on 15 June 2017).

60. Istituto Nazionale di Geofisica e Vulcanologia. (c) Data of the Shock of 30 October 2016. Available online: https:/ /ingvterremoti.files.wordpress.com/2016/12/relazionedettaglio_30ott_m6-5.pdf (accessed on 15 June 2017).

61. Istituto Nazionale di Geofisica e Vulcanologia. (d) Data of the Shock of 18 January 2017. Available online: https: / ingvterremoti.files.wordpress.com/2017/01/relazione-di-dettaglio-dei-3-eventi-di-m_-50-del-2017-01-18.pdf (accessed on 15 June 2017).

62. Q-GIS, software version 2.18.4; with GRASS 7.2.0.; Q-GIS Development Team: Girona, Spain, 2018.

63. Casolo, S. A numerical study on the cumulative out-of-plane damage to church masonry facades due to a sequence of strong ground motion. Earthq. Eng. Struct. Dyn. 2016, 1-22. [CrossRef]

64. Parisi, M.A.; Sferrazza Papa, G. Chiese nel terremoto del Centro Italia: Confronti e osservazioni. In Atti del IV Convegno di Ingegneria Forense, VII Convegno su Crolli, Affidabilità Strutturale, Consolidamento, Proceedings of Convegno IfCrasc17, Milan, Italy, 14-16 September 2017; Augenti, N., Jurina, L., Eds.; Volume 2, pp. 277-285, ISBN 9788857907208.

65. Istituto Nazionale di Geofisica e Vulcanologia Site. Available online: http:/ /www.ingv.it/it/ (accessed on 28 February 2018).

(C) 2018 by the authors. Licensee MDPI, Basel, Switzerland. This article is an open access article distributed under the terms and conditions of the Creative Commons Attribution (CC BY) license (http:// creativecommons.org/licenses/by/4.0/). 